\title{
COMPREHENSIVE EVALUATION OF THE ENVIRONMENTAL HAZARD CAUSED BY THE OPERATION OF AUTOMOTIVE VEHICLES
}

\author{
ZDZISŁAW CHLOPEK', JAKUB LASOCKI
}

Warsaw University of Technology

\section{Summary}

The paper presents authors' views about comprehensive evaluation of the environmental hazard caused by the operation of automotive vehicles. Methods of analysing the emissions of environmental pollutants and the energy input at the stage of production and distribution of energy carriers (from the source of obtaining an energy carrier to the fuel tank, "Well-to-Tank," abbreviated as WtT) and at the stage of vehicle use (from the fuel tank to the vehicle wheel, "Tank-to-Wheel," abbreviated as TtW) have been described. Results of the research carried out in compliance with the Eco-indicator 99 procedures and with the Swiss Ecological Scarcity Method, also known as the Ecoscarcity or UBP'06 method, have been analysed. In the recapitulation, the authors have criticised the existing methods of assessment of the harmful environmental impact of motorisation and proposed an original system of indicators that would characterise, in terms of pollutant emissions, the energy-related and environmental impacts exerted by motor transport at the stages of the production and distribution of energy carriers and the use of automotive vehicles.

Keywords: motorisation, pollutant emissions, Well-to-Wheel analysis, alternative fuels.

\section{Introduction}

Due to the commonness and large-scale of motorisation, the public feeling of its environmental impact far exceeds reasonable limits. In some ways, however, this is justified because we even intuitively feel, at every turn, the environmental nuisance caused by motor transport, especially in urban agglomerations and in the areas surrounding transport routes. The need to evaluate the environmental hazard caused by motorisation is unquestionable because the rationalisation of development of motor transport, which is essential for the community to function, requires the having of tools for the gaining of not only qualitative but also quantitative knowledge of the environmental risks related

' Warsaw University of Technology, Faculty of Automotive and Construction Machinery Engineering, 84 Narbutta Street, 02-524 Warszawa, zchlopekอsimr.pw.edu.pl, ph.: +4822 2348559

${ }^{2}$ Warsaw University of Technology, Faculty of Automotive and Construction Machinery Engineering, 84 Narbutta Street, 02-524 Warszawa, jakub.lasocki@gmail.com, ph...+48 511092733 
to this type of human activities. This task is the more so difficult that it is impossible to set clearly defined boundaries in the areas of human activities more or less closely, directly or indirectly, related to motorisation. The motorisation-related environmental impacts are chiefly exerted by automotive vehicles; nevertheless, the impacts of automotive equipment manufacturing plants as well as service and road traffic infrastructure cannot be ignored, either. Among the factors related to motor transport that affect the environmental quality, the consumables, especially fuels, and the facilities where such materials are produced occupy an important position. The other items, which may be mentioned as ranked somewhat lower, include the mining industry, power industry, etc. There is no clearly defined end of this list. The types of the environmental impact exerted by motorisation are also very complex, ranging from road accidents through the emissions of pollutants, electromagnetic radiation, noise, vibration, and leaking consumables, to the occupation of territory and landscape degradation.

It can be seen, therefore, that the comprehensive evaluation of the environmental impact of motorisation must be based on clearly defined boundaries and that some assumptions must be adopted for the evaluation to be made generally possible. In most cases, the evaluation is limited to the emission of pollutants harmful to people's environment, especially to human health. It is very often that the research work is confined to the conditions of use of automotive vehicles. Even at these severe limitations, the assigning of specific harmfulness weights to individual pollutants, which would make it possible to compare the situations examined, gives rise to significant difficulties. An example of the attempts made to solve this problem is the algorithm of assigning the environmental loading costs to individual selected substances as proposed in Directive 2009/33/EC on the promotion of clean and energy-efficient vehicles. Another serious issue is the adoption of comparable models of the state of operation of internal combustion (IC) engines, representative for the use of such engines in automotive vehicles. This problem is the more so important that, as it is widely known, pollutant emissions are very much sensitive to the state of operation of IC engines, especially to the occurrence of dynamic states.

In connection with the spreading interest in the application of renewable energy carriers, the need to evaluate pollutant emissions and energy inputs with taking into account the production and distribution of these carriers becomes increasingly pressing. Very often, the public interest is limited in such cases to merely the emission of greenhouse gases (GHG), especially carbon dioxide, which results more from propaganda than from rational reasons. The fact that the hazards causing immediate danger to human health are neglected in this context is a sign of not only light-heartedness of incompetent ideologists but also of irresponsibility of the persons in whom communities naively placed their trust.

The subject matter of the deliberations presented here is the comprehensive evaluation of pollutant emissions and energy inputs related to the production and distribution of energy carriers and to the use of the energy carriers in vehicles. For this purpose, examples drawn from Western Europe, predominantly from Switzerland, were used. By citing these examples, the authors try to show significant relativity of results of such analyses and recommend being careful when researching this topic. 
The research methods cited here are burdened with significant formal weaknesses. For this reason, the authors try, if possible, to avoid the informalities and clumsy expressions occurring in the original materials, inter alia by translating into Polish the commercialised English terms so typical for the western civilisation, which are linguistically defective and ill befit the scientific work. One of the most important clumsy and incorrect terms is the "life" applied to inanimate objects. The common terms of the kind of "vehicle life cycle" are a sign of marketing commercialisation of the language. The authors consistently use the term "vehicle existence," regretting that they could not find an appropriate word in place of "cycle," as the existence of a vehicle actually has not the nature of a cyclic process. Perhaps, the term "vehicle existence time" would be better than the "vehicle existence cycle." There are also serious difficulties in the assimilation in the Polish science of the terms that have not been formalised in the original sources, such as e.g. "current flow," which, may be, have a high literary value but whose quality as scientific terms is definitely poor.

In spite of these difficulties in the comprehensive evaluation of the harmful environmental impact of motorisation, the authors are aware of the necessity to undertake such actions, seeing a lower risk in the employing of minimalist solutions in the assessments, e.g. in the form of significant limitation to the generality of the analyses carried out.

\section{Assumptions made for the analysis of the environmental hazard in the cycle of existence of an automotive vehicle}

The environmental hazards resulting from the whole conventional cycle of existence of an automotive vehicle are summed up in most cases with the use of a predefined method and appropriate computer software (because of a great number of data and, sometimes, complicated calculation algorithms). One of the most popular methods is the analysis "Well-

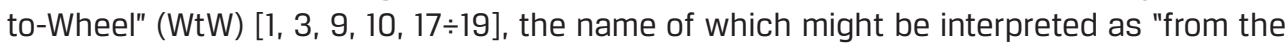
source (of an energy carrier) to the wheel (of a vehicle)" [5, 8]. The Well-to-Wheel analysis is applicable to the determining of emissions of environmental pollutants (greenhouse gases in most cases) and energy input, resulting from the use of fuels of various types and the corresponding types of possible vehicle propulsion systems. In such an analysis, the whole conventional fuel existence cycle is taken into account, which covers the acquisition of primary energy carriers, processing of the carriers to convert them into energy carriers usable for the propulsion of vehicles, transport and distribution of the energy carriers, and final pollutant emissions from the vehicle during operation. In practice, the Well-to-Wheel analysis is divided into two stages (Fig. 1) $[1,3,5,10,13,15,17,18]$ :

- From the source of an energy carrier to the fuel tank (Well-to-Tank, WtT);

- From the fuel tank to the vehicle wheel (Tank-to-Wheel, TtW).

As the final output of the analysis, the total energy consumption and the total pollutant (greenhouse gas) emissions are determined at both the stages. 


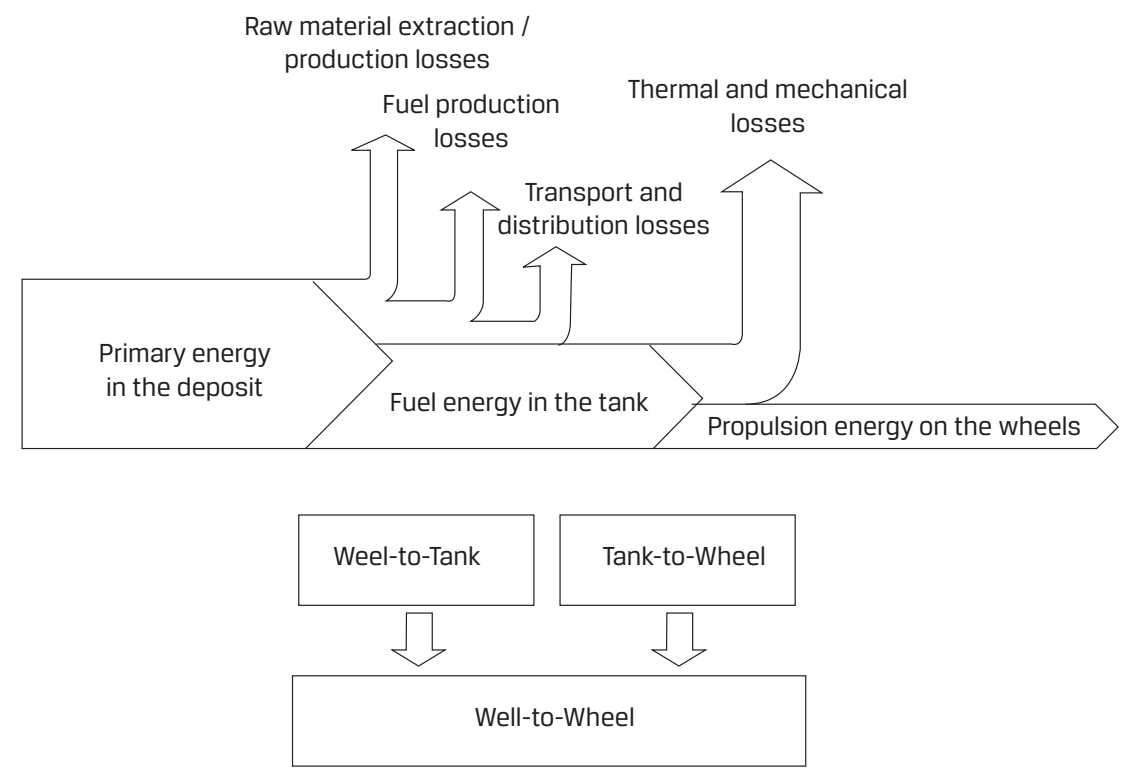

Fig. 1. Schematic diagram of the Well-to-Wheel analysis.

The first part of the analysis, i.e. the Well-to-Tank stage, covers the fuel preparation processes, namely from the production or extraction of raw materials (primary energy carriers), through raw material processing, fuel transport and distribution, to the placing of the fuel in a vehicle fuel tank. The total efficiency of this stage, referred to as total fuel preparation efficiency, defined as the ratio of the amount of the energy contained in finished fuel (without the energy needed for the fuel preparation) to the amount of the primary energy contained in the unprocessed energy carrier, may be determined (Table 1) [13]. The energy losses and the amounts of pollutant emissions resulting from the fuel preparation process depend not only on the fuel type but also on the production method adopted and the feedstock used. That is, if there is a number of possible methods of production of a specific fuel (for example, hydrogen may be obtained by steam reforming of methane, coal or biomass gasification, biomass pyrolysis, or electrolysis of water), then the final balance of energy consumption and pollutant emissions will depend on which of the production methods is taken as a basis for the analysis. 
Table 1. Relative energy losses occurring during the cycle of preparation of diesel fuel, motor gasoline, compressed natural gas (CNG), and compressed hydrogen and the total fuel preparation efficiency determined for these fuels (based on [13]).

\begin{tabular}{|l|c|c|c|c|}
\hline Actions that cause energy losses & $\begin{array}{c}\text { Diesel } \\
\text { fuels }\end{array}$ & $\begin{array}{c}\text { Motor } \\
\text { gasoline }\end{array}$ & $\begin{array}{c}\text { Natural gas } \\
\text { (CNG) }\end{array}$ & Hydrogen \\
\hline $\begin{array}{l}\text { Extraction, preconditioning, and } \\
\text { long-distance transport }\end{array}$ & 0.03 & 0.03 & 0.01 & 0.1 \\
\hline $\begin{array}{l}\text { Processing (refining / steam } \\
\text { reforming) }\end{array}$ & 0.06 & 0.08 & 0 & 0.2 \\
\hline $\begin{array}{l}\text { Domestic distribution (quick filling } \\
\text { stations for CNG and hydrogen) }\end{array}$ & 0.02 & 0.02 & 0.12 & 0.17 \\
\hline $\begin{array}{l}\text { Total fuel preparation efficiency } \\
\text { (with the fuel energy value having } \\
\text { been taken into account) }\end{array}$ & 0.89 & 0.86 & 0.8 & 0.6 \\
\hline
\end{tabular}

Many literature items and thorough reports were published, where not only results of Wellto-Wheel analyses but also types of the factors taken into account in the calculations were presented. The most important factors that have an impact on the evaluation of fuels at the fuel preparation stage have been discussed in this paper, based on publications [1, $2,3,9,10,13,14,17 \div 19]$.

In the rolling analysis of biofuels obtained from energy plants, the energy losses and environmental pollution resulting from the plant growing process should be considered. For example, such factors are taken into account as diesel oil consumption by farm machinery, application of nitrogenous fertilisers, quantity of water used, or conventional values of the emissions related to the land-use change in the areas earmarked for the cultivation of plants to be used for the production of biofuels. These factors may be ignored, i.e. their values may be assumed as zero, in the case of fuels obtained from waste biomass. Particularly valuable is the possibility of reduction of the carbon dioxide emission thanks to the fact that this gas is assimilated by plants when they are growing; thus, this quantity becomes negative in the final balance. The method of utilisation of the by-products generated when the biomass is processed is also an important aspect. A part of the by-products may be used in other industry branches, e.g. the glycerine generated during the biodiesel production process finds application in the pharmaceutical, cosmetic, papermaking, and other industries, and fodder for animals is obtained at the process of making biomass from cereals. Such by-products can be substituted for products made traditionally, which helps to reduce energy consumption and pollutant emissions. The emissions generated during the fuel production process are usually divided among the fuel and the by-products, proportionally to their energy content. Much controversy is aroused by the fact that some materials suitable for other purposes, e.g. cereals for the production of food and fodder, sugar reed for the production of sugar, or wood for the generation of heat, are used for the production of biofuels. In the energy balance, the availability of such an alternative solution is considered a negative factor. 
As opposed to biofuels, the method of obtaining natural gas is far less complicated. The main factors that should be taken into account at the stage from the source of raw material to the fuel tank are extraction, transport by pipelines, and compression (CNG) or liquefaction (LNG) at filling stations.

In the analysis of the hydrogen preparation process, the factor of the most significant importance is the production method employed. In the case of steam reforming of natural gas, which is now the most popular method, particular attention is paid to the transport of natural gas, the steam reforming process as such, and the hydrogen compression at the filling station. If, however, hydrogen has been generated in result of electrolysis of water, it is important for the compiling of an energy and emission balance that the origin of the electricity used for the process should be ascertained. Hydrogen is considered "clean" (bio-hydrogen) if it has been generated with the use of electricity obtained from renewable sources (wind power farms or solar power stations). Otherwise, the emissions accompanying the process of obtaining electric energy should be taken into account in the balance of emissions determined for the hydrogen subject to the analysis.

Conventional fuels are characterised by significant energy demand for the extraction of crude oil and for the transport of the oil to a refinery, then for the oil refining to obtain diesel fuel or gasoline, and for the transport of these products to the final consumers. The results of the balance compiled for petroleum-derivative fuels at the Well-to-Wheel analysis are often taken as a reference to compare the environmental properties of unconventional fuels of various kinds.

The above examples of the data used for the Well-to-Tank analyses have been given here as rough information only. Actually, almost each of the operations presented here may be carried out in several different ways, e.g. waterborne, rail, and road transports are connected with different energy inputs and pollutant emissions. Therefore, the evaluation of a specific fuel is very sensitive to the assumptions made.

At the second stage, from the fuel tank to the vehicle wheel (Tank-to-Wheel), the pollutant emissions from the vehicle and the fuel consumption by the vehicle are evaluated. The factors of critical importance for this part of the analysis are the type of the fuel used, the type of the exhaust gas treatment system, and the total efficiency of the vehicle propulsion system [13], which is the highest for fuel cells, lower for diesel engines, and the lowest for spark-ignition engines (hybridisation with the use of an electric motor makes it possible to achieve an extra growth in the total efficiency) [1].

The necessary tests are usually carried out in laboratory conditions, on chassis dynamometers (for complete vehicles) or on engine test beds (for engines only), with tests of various kinds, both static and dynamic, being run. Normally, the tests provided in type validation procedures are used, but this, in principle, does not give grounds for the formulation of conclusions about the engine performance in actual service conditions. This is the most serious weakness of the generally applied methods of analysing the environmental impact of motorisation. Admittedly, the use of validation test procedures for the engine tests makes it possible to carry out comparative analyses of energy and pollutant emission effects, but the formulation of judgments on the inventorying of energy 
and pollutant emissions, which is a common practice among both specialists and people of action, i.e. propagandists and politicians, is absolutely inacceptable.

Regardless of methodological reservations, at least in researchers' intention, the final output of the Well-to-Wheel analysis is the sum of energy spent and the total mass of the pollutants emitted at both the stages of the analysis, i.e. the fuel preparation (Well-to-Tank) and the use of fuel in the vehicle (Tank-to-Wheel).

Based on the energy balance, the amount of energy is determined that is needed for the preparation of the fuel consumed by the vehicle to travel a road section of unit length (expressed in $[\mathrm{MJ} / \mathrm{km}]$ or $[\mathrm{MJ} / \mathrm{mi}]$ ). Usually, other indicators are also specified, e.g. the

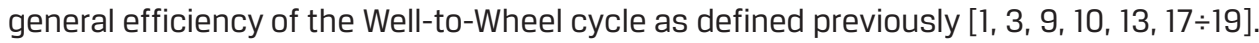

To calculate the balance of the emissions of greenhouse gases (carbon dioxide and, inter alia, methane and dinitrogen monoxide) for the whole cycle, the emissions are converted into equivalent emissions of carbon dioxide $\mathrm{CO}_{2 \mathrm{eq}}$ and then summed up. Individual gases are given appropriate values of carbon dioxide equivalent, proportional to the potential share of the gases in the development of the greenhouse effect (the numerical values have been taken from Directive 2009/28/EC):

- Carbon dioxide $\quad-\quad 1 ;$

- Dinitrogen monoxide - 296;

- Methane $\quad-23$.

This procedure facilitates the calculation of greenhouse gas emissions and the final interpretation and comparison of results. In general terms, the emission of greenhouse gases is specified as mass emission of carbon dioxide equivalent, i.e. the mass of carbon dioxide equivalent emitted during the process of fuel preparation and use in a vehicle in relation to the distance travelled by this vehicle (expressed in $[\mathrm{g} / \mathrm{km}]$ or $[\mathrm{g} / \mathrm{mi}]$ ) or as an energy-related indicator of the emission of carbon dioxide equivalent, i.e. the mass of carbon dioxide equivalent emitted during the process of preparation and combustion of a fuel amount carrying $1 \mathrm{MJ}$ of energy (expressed in $[\mathrm{g} / \mathrm{MJ}]$ ) $[1,3,9,10,13,17 \div 19]$.

Detailed rules of the calculation of greenhouse gas emissions at the Well-to-Tank stage for various biofuels used in the EU countries are laid down in Directive 2009/28/EC of the European Parliament and of the Council of 23 April 2009 on the promotion of the use of energy from renewable sources. The provisions of this Directive constitute a basis for the assessment whether each of the EU member states manages to achieve the planned minimum share of energy from renewable sources in the gross final energy consumption in 2020 (the so-called "national overall target"). Pursuant to the Directive, the total energyrelated indicator of the emission of carbon dioxide equivalent (in other words, greenhouse gases or $\mathrm{GHG}$ ) should be determined from a formula as given below:

$$
W E=W E_{e c}+W E_{l}+W E_{p}+W E_{t d}+W E_{u}-W E_{s c a}-W E_{c c s}-W E_{c c r}-W E_{e e}
$$

where:

$\mathrm{WE}_{\mathrm{ec}}$ - energy-related GHG emission indicator determined for the emissions from the extraction or cultivation of raw materials; 
$\mathrm{WE}_{1}$ - energy-related GHG emission indicator determined for the annualised emissions from carbon stock changes caused by land-use change;

$\mathrm{WE}_{\mathrm{p}}$ - energy-related GHG emission indicator determined for the emissions from processing;

$\mathrm{WE}_{\mathrm{td}}$ - energy-related GHG emission indicator determined for the emissions from transport and distribution;

$W_{u}$ - energy-related GHG emission indicator determined for the emissions from the fuel in use;

$\mathrm{WE}_{\text {sca }}$ - reduction of the energy-related GHG emission indicator determined for the emission saving from soil carbon accumulation via improved agricultural management;

$\mathrm{WE}_{\text {ccs }}$ - reduction of the energy-related $\mathrm{GHG}$ emission indicator determined for the emission saving from carbon capture and geological storage;

$\mathrm{WE}_{\text {ccr }}$ - reduction of the energy-related $\mathrm{GHG}$ emission indicator determined for the emission saving from carbon capture and replacement;

$\mathrm{WE}_{\mathrm{ee}}$ - reduction of the energy-related GHG emission indicator determined for the emission saving from excess electricity from cogeneration.

Definitions of the quantities specified in the formula above as well as their values or methods of calculation, depending on biofuel type, production method, and raw material used for the production, have been given in the Directive.

An example of results of calculations of the total energy-related indicator of the emission of carbon dioxide equivalent (total energy-related GHG emission indicator) from plant cultivation as well as from the production (with various process methods employed), transport, and distribution of selected biofuels has been presented, in a summarised form, in Fig. 2.

Many times, when the environmental hazards caused by the operation of automotive vehicles are analysed, not only total emissions and energy consumption but also other additional comparative factors are taken into account. Some of them make it possible to compare the environmental impact of a vehicle in several aspects, with qualitative assessment being taken as the objective. An example is the "eco-indicator" determined in the Eco-indicator 99 method $[12,16]$, in which environmental impact assessments in the following three damage categories are combined together:

- Damage to human health;

- Damage to ecosystem quality;

- Damage to resources.

The damage to human health is expressed in this method by the DALY indicator (DisabilityAdjusted Life Year), which is a unit of measure of the impact of ill-health on the human being in terms of both the life time lost because of premature death (mortality) and the time lived 


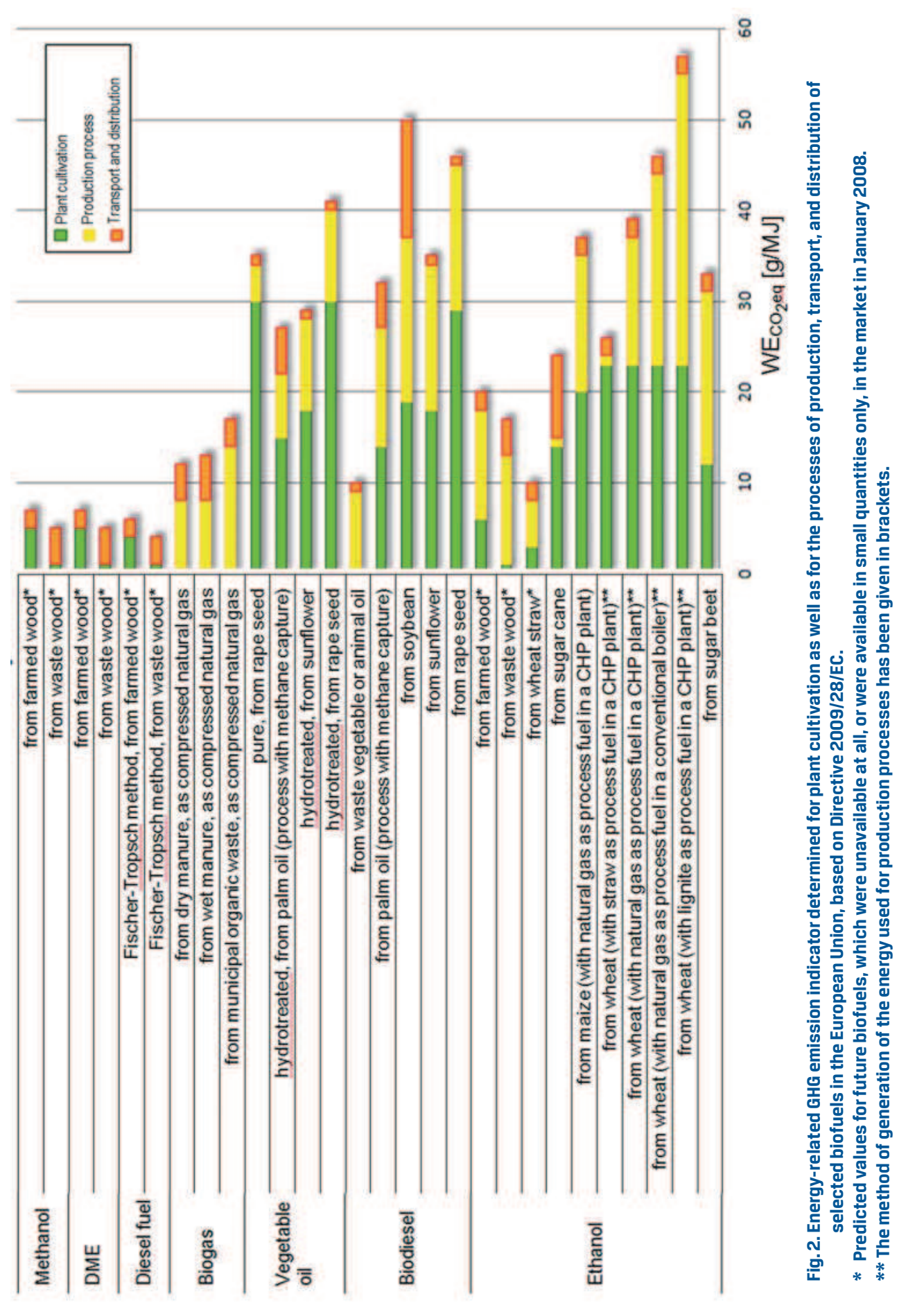


in the state of disability (morbidity). This indicator is commonly used in health economy to define the state of health of a specific population, e.g. by the World Health Organization (WHO). In the Eco-indicator 99 method, models have been developed where respiratory diseases, tumours, climate change effects, ozone layer depletion (causing such diseases as cutaneous carcinoma or cataract), and harmful impact of ionising radiation have been taken into account and where the quantities measured include exposure to pollutants and pollutant immissions.

The damage to ecosystem quality is determined as the percentage of the species that vanish in a specific area due to the environmental impact of vehicles or fuel production processes. In this case, such factors are taken into account as water and soil acidification and eutrophication, land-use change (e.g. deforestation), and "ecotoxicity", defined as the percentage of all the species present in the environment within a certain area and within a specific time interval and living under toxic stress (Potentially Affected Fraction or PAF) [16].

In the third damage category, the resource depletion is assessed in terms of the quality of the remaining raw material resources, including petroleum-derivative fuels. It is determined as the surplus energy that will have to be spent in the future for the extraction of $1 \mathrm{Mg}$ of the raw material (expressed in $[\mathrm{MJ} / \mathrm{Mg}]$ ). In some cases, the scale of extraction of other chemical elements and compounds is considered.

In its final form, the eco-indicator is a figure that is the sum of the figures obtained for the three damage categories and weighted as appropriate. Moreover, the Eco-indicator 99 method makes it possible to select one of three "interpretation perspectives," i.e. "hierarchist," "egalitarian," or "individualist," which determine the weights of each of the three damage categories. As default, the hierarchist perspective is used, where the contribution of human health and ecosystem quality is $40 \%$ each and the contribution of the resource depletion is considered to be as low as $20 \%$. In the case of the egalitarian perspective, the ecosystem quality is given the highest weight, i.e. $50 \%$, while the weights of the human health and resources are $30 \%$ and $20 \%$, respectively. In the individualist approach, the human health predominates with a weight of 55\%; the second and third importance levels are given to ecosystem quality $(25 \%)$ and resources $(20 \%)[12,16]$.

Based on the Eco-indicator 99 method, over 200 eco-indicator values have been calculated for the most frequently used materials and processes. Computer databases, based on existing eco-indicators and making it possible to calculate new items, have been created as well to support the environmental impact assessment (e.g. SimaPro [12]).

A slightly different approach has been adopted at the Swiss Ecological Scarcity Method [11], sometimes referred to as Ecoscarcity or UBP'O6 (from German "Umweltbelastungspunkte") method. As it is in the case of the Eco-indicator 99 method, a few areas of the environmental impact of the product or process under investigation (e.g. the operation of an automotive vehicle) are taken into account. In this method, chiefly the pollutant emissions (with such factors as acidification and eutrophication, ozone layer depletion, etc.) and the use of natural raw materials are taken into account. The unique nature of this method lies in 
the determining of the distance between the current environmental loading in a specific area, i.e. "current flow," and the maximum acceptable loading defined by the existing legislative guidelines or political goals, referred to as "critical flow." The terms of "current flow" and "critical flow" have not been formalised yet; therefore, they should be judged as a method, typical for the commercial trends in the academic research in the West, of vivid and pompous presentation of results of intellectual activities. We may suppose that the "current flow" and "critical flow" are physical quantities that define the environmental impact of civilisation, e.g. pollutant immissions, mass emission, or specific brake emission of pollutants from internal combustion engines. According to the Swiss method, the result of the environmental impact assessment is presented in the form of an "eco-factor," the unit of which has been defined as the so-called eco-point (EP) divided by the unit of measure of the polluting effect under consideration (for the emission of greenhouse gases, the eco-factor would be expressed in $[\mathrm{EP} / \mathrm{g}])$. The eco-factor is calculated from the following formula:

$$
\text { eco-factor }=K \cdot \frac{1 \cdot E P}{F_{n}}\left(\frac{F}{F_{k}}\right)^{2} \cdot c
$$

where:

$\mathrm{K}$ - coefficient of relative harmfulness of the specific polluting effect;

F - current flow;

$\mathrm{F}_{\mathrm{n}}$ - normalised flow;

$\mathrm{F}_{\mathrm{k}}$ - critical flow;

c - constant.

Hence, the eco-factor may be defined as a measure of the potential environmental hazard imposed by a specific polluting effect. Its value rises with growing excess of the current emission or consumption of natural raw materials over the limits allowed. The coefficient of relative harmfulness of the polluting effect under consideration, present in the formula, is to adjust the calculation result by differentiating substances that exert more or less harmful environmental impact (as it is in the case of greenhouse gases). The current flow value is usually taken from the most recent statistical data available for the specific area.

The main good points of the Swiss ecological scarcity method are simplicity of calculations and direct relationship with the political targets and legislative limits that should be met in a specific area or country. This is the main difference between this method and the methods that are oriented at absolute evaluation of environmental damage (such as the Eco-indicator 99 method). On the other hand, however, the eco-factor values may only be determined for the substances for which any legislative limits or political targets actually exist. 


\section{Examples of analyses of greenhouse gas emissions in the cycle of existence of an automotive vehicle}

It should be stressed that the result of an analysis carried out with the use of the Wellto-Wheel method greatly depends on the scope of investigation as adopted by the researchers, inclusive of the number and weights of the factors under consideration as well as the assumptions made and simplifications adopted; therefore, it should exclusively be considered together with all these issues being taken into account. For this reason, the analysis results published in $[1,3,10,14,17 \div 19]$ are not always fully consistent with each other; sometimes, they are even discrepant. In the literature items published in the recent years, compared with older publications, more factors that are indirect are in general taken into account, e.g. the carbon dioxide emission related to a change in the use of land allocated for the cultivation of plants intended for biofuel production $[2,14,19]$.

Interesting results of investigations carried out with the use of the Well-to-Wheel method have been presented in [19], where environmental properties of a few non-renewable fuels, i.e. motor gasoline, diesel fuel, and natural gas, have been compared with the properties of 26 biofuel types made with the use of various raw materials and process methods available in Switzerland. Five conventional processes being parts of the fuel existence cycle were analysed: plant cultivation (if applicable), fuel production, transport of the fuel to a filling station, use of the fuel in vehicles, as well as construction and maintenance of infrastructure. To assess the environmental impact of these processes, a concept based on the following two indicators was proposed:

- Emission of greenhouse gases (in the form of carbon dioxide equivalent);

- Total environmental balance (ökologische Gesamtbilanz).

The value of the total environmental balance was calculated for each fuel type with the use of two different methods, i.e. the Swiss ecological scarcity method (eco-factor) and the Eco-indicator 99 method (eco-indicator) (Fig. 3).

Fig. 4 shows the indicator data determined for selected biofuels and presented in relation to the corresponding values obtained for gasoline, in the form of relative eco-factor vs. relative energy-related GHG emission indicator. An analysis of the results obtained by the authors gives grounds for a statement that most of the biofuels considered (21 of 26) reduces the greenhouse gas emissions by more than $30 \%$ in relation to the emissions determined for the corresponding grades of motor gasoline. On the other hand, nearly a half of the biofuels (12 of 26) exerts more harmful environmental impact than fossil fuels. This group includes the biofuels produced now on the largest scale, i.e. maize bioethanol (the USA), soybean biodiesel and sugar cane bioethanol (Brazil), and palm oil biodiesel (Malaysia). Much better environmental properties can be observed for biofuels made from waste stock, e.g. from waste vegetable oil, and for ethanol produced from wood or grass. These results have highlighted the differences between the gains and losses related to the use of individual biofuels [14, 19]. 


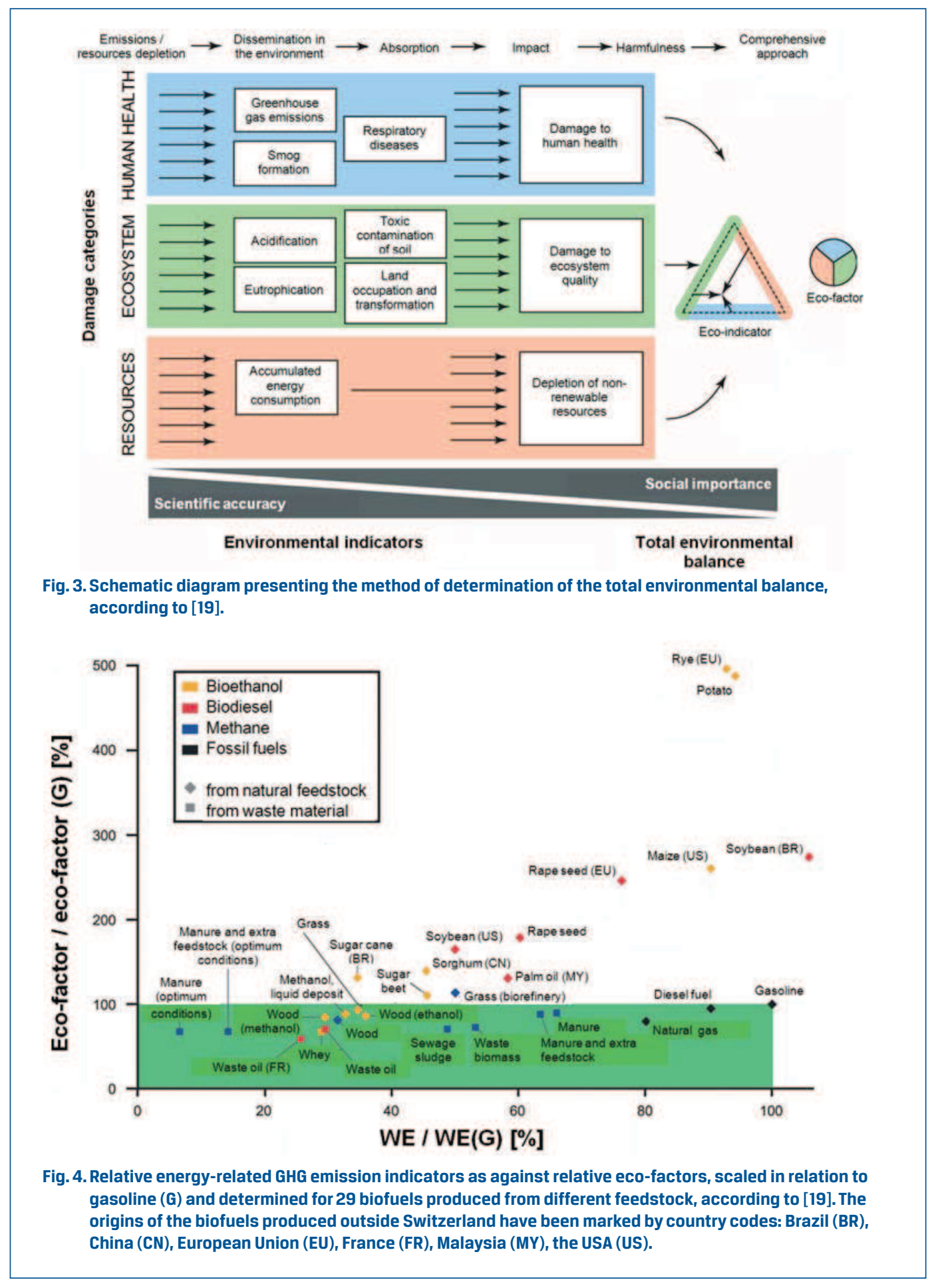


The mass emissions of greenhouse gas and eco-factors determined for specific processes being parts of the existence cycle of the fuels under consideration have been shown in Figs. 5 and 6. In principle, the highest values of both indicators (although for not all fuels) occur during plant cultivation processes because of the use of farm machinery, fertilisers, and pesticides and, apart from this, in result of other factors such as soil acidification and biodiversity loss, especially in tropical zones. The production process is the second largest source of greenhouse gas emissions while the transport of fuels to the Swiss filling stations only insignificantly contributes (below $10 \%$ ) to the generation of emissions and other environmental hazards $[14,19]$.

The analysis results may be considered attractive because they cover a wide range

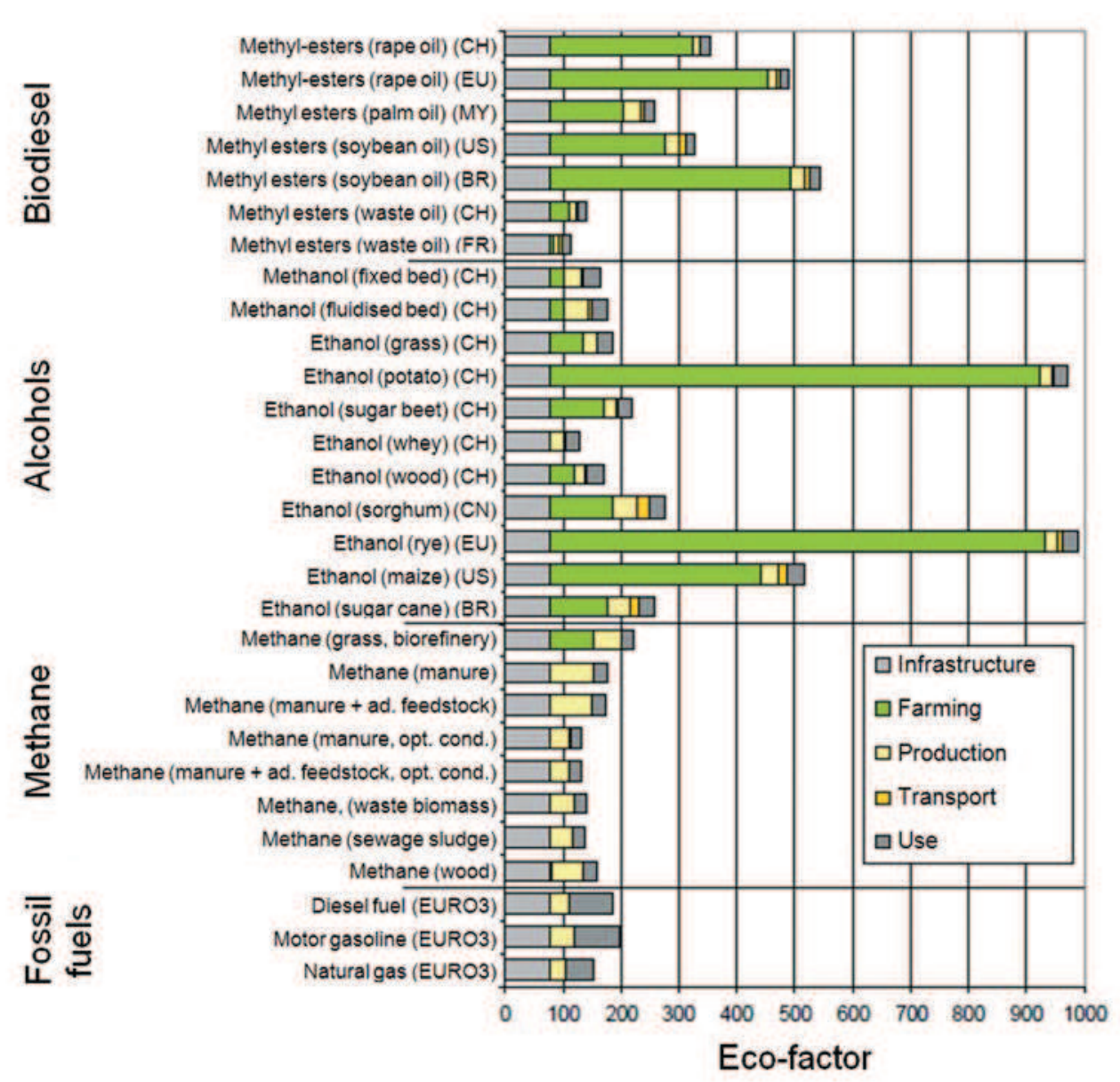

Fig. 5. Comparison of the eco-factors for biofuels and fossil fuels determined by the Well-to-Wheel method, according to [19]. The origins of the biofuels are: Switzerland (CH), Brazil (BR), China (CN), European Union (EU), France (FR), Malaysia (MY), and the USA (US). 
of input data and many fuel types. In spite of this, the method employed is not perfect. The attempt to describe a combination of various environmental hazards with a single indicator carries a lot of risk; however, both the methods employed (Ecoscarcity and Ecoindicator 99) returned identical results. On the other hand, much more doubts are raised by the fact of ignoring potential indirect effects connected with the biofuel market, e.g. the relationship between increase in biofuel demand and enlargement of the land used for the cultivation of energy plants at the cost of natural ecosystems as well as economic and social factors. Apart from this, in consideration of incompleteness of the data available, the authors did not take into account some biofuels produced from lignocellulosic feedstock, which is useless in the food industry $[14,19]$.

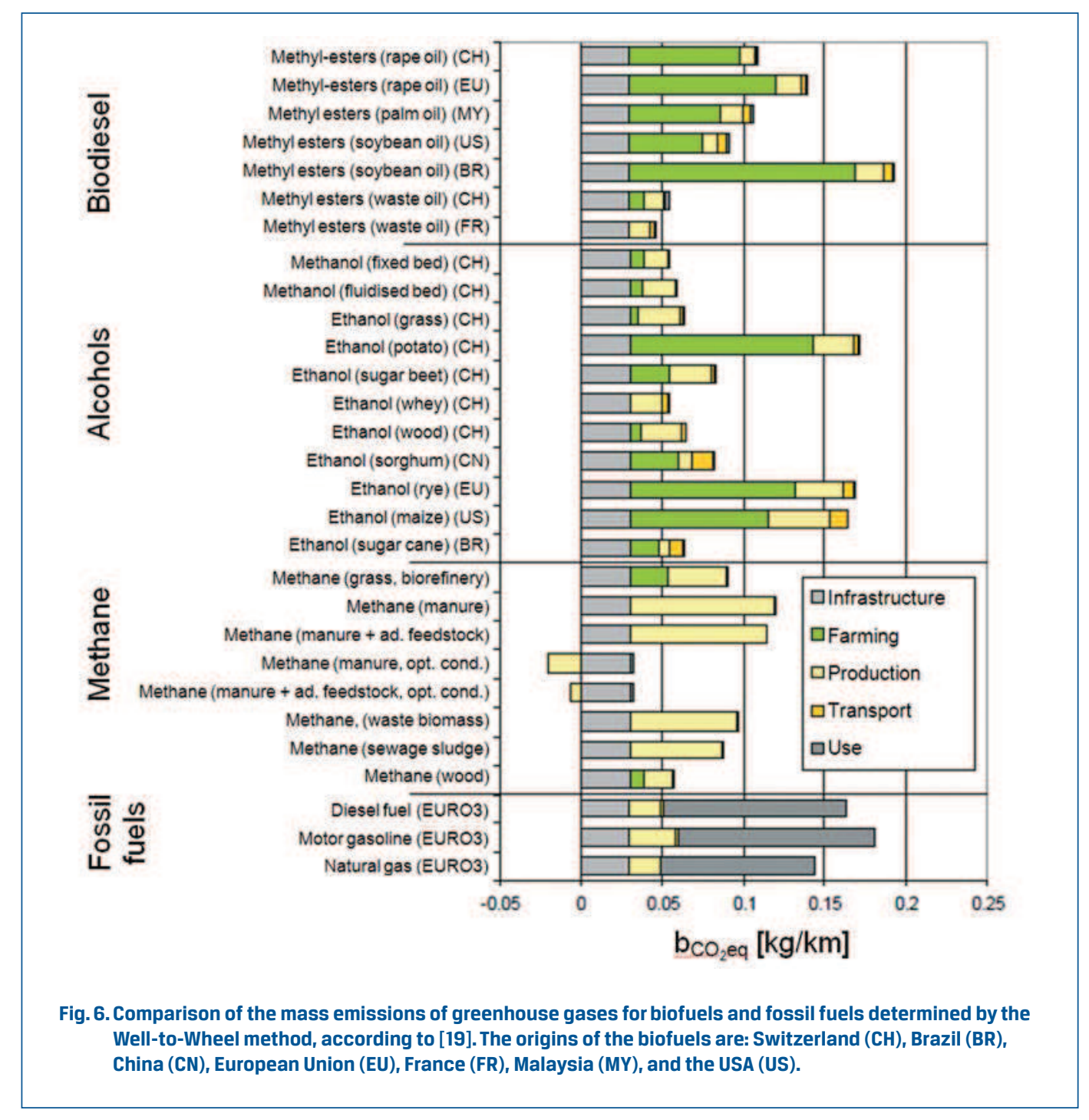




\section{Recapitulation}

Until now, the most popular methods of comprehensive evaluation of the environmental impact of motor transport have been restricted to, above all, the analysis of energy input and pollutant emissions from automotive vehicles, with taking into account the stages of the production and distribution of energy carriers and the use of automotive vehicles. The knowledge of the methods to evaluate the economic performance based on fuel consumption and the environmental characteristics based on pollutant emissions during vehicle use is much more extensive than that concerning the fuel preparation stage, although there are still many factors related to the vehicle use stage that are difficult for being standardised but have a strong impact on the evaluation results. The most important uncertainties concern the identifying of the IC engine operating conditions that affect the engine operation states having the greatest impact on pollutant emissions. Against these problems, however, the susceptibility of environmental and energy-related properties of energy carrier preparation processes to individual carriers and their preparation methods is incomparably higher. Therefore, the results of such analyses should be considered not only as combined together but also separately because significant reserves may be hidden in the processes of production and distribution of energy carriers while the effects of any changes possible to be introduced at the vehicle use stage are usually quite small. This means that any benefits that might be gained at the vehicle use stage would be far more valuable in comparison with those achievable in connection with the process of supplying energy carriers.

Another important issue is the attitude taken to specific pollutants. Currently, it is generally in vogue to believe that the most important pollutants, equated in many cases with environmental properties, are greenhouse gases, usually simplified to carbon dioxide only, often with forgetting that in the case of the use of renewable energy carriers this should only be applied to the fossil carbon dioxide. Such an approach is not only erroneous but also damaging, because the substances that are most dangerous for people are those being directly harmful to human health. Sometimes, comprehensive evaluation methods are created that make it possible to take into account the emissions of substances harmful to people's health and contributing to the intensification of the greenhouse effect. An example of such an approach seems to be the proposal put forward in Directive 2009/33/EC on the promotion of clean and energy-efficient road transport vehicles. Actually, the difference between the fossil and non-fossil carbon dioxide is not distinguished in this Directive, which puts the use of renewable fuels in a lost position. Hence, it is right to consider separately the indicators exclusively concerning the emissions of substances harmful to human health and those concerning the emissions of the pollutants that may damage the environment. For humanistic reasons, therefore, priority in comprehensive evaluations of the motor transport should be given to the indicators that concern the emissions of substances harmful to human health at the vehicle use stage because they describe the greatest and immediate danger threatening people from the motor transport.

In consequence, the authors propose the following systematisation of indicators for comprehensive evaluation of energy balance and pollutant emissions from automotive vehicles at the energy carrier production and distribution (WtT) stage and the vehicle use (TtW) stage: 
- Indicators describing the emissions of substances harmful to human health at the WtT stage, given the symbols of $b_{\text {tox } \mathrm{WtT}_{\mathrm{t}}}$ for road emissions and $\mathrm{WE}_{\text {tox } \mathrm{WtT}_{\mathrm{T}}}$ for energy-related emission indicator;

- Indicators describing the emissions of substances harmful to the environment at the WtT stage, given the symbols of $b_{\text {eco } W_{t T}}$ for road emissions and $\mathrm{WE}_{\text {eco } \mathrm{WtT}_{\mathrm{T}}}$ for energyrelated emission indicator;

- Indicator describing the energy-related effect at the WtT stage, given the symbol of efficiency $\eta_{\mathrm{wtT}}$;

- Indicators describing the emissions of substances harmful to human health at the TtW stage, given the symbols of $\mathrm{b}_{\text {tox TtW }}$ for road emissions and $\mathrm{WE}_{\text {tox TtW }}$ for energy-related emission indicator:

- Indicators describing the emissions of substances harmful to the environment at the $\mathrm{TtW}$ stage, given the symbols of $\mathrm{b}_{\text {eco TtW }}$ for road emissions and $\mathrm{WE}_{\text {eco TtW }}$ for energyrelated emission indicator;

- Indicator describing the energy-related effect at the $\mathrm{TtW}$ stage, given the symbol of efficiency $\eta_{\mathrm{TtW}}$.

In the comprehensive evaluation of the environmental hazard caused by motor transport, the top priority should be given to the indicator describing the emissions of substances harmful to human health at the $\mathrm{TtW}$ stage, i.e. at the stage of the use of automotive vehicles.

The authors are convinced that prudence of decision-making communities' representatives will induce them to adopt rational approach to the issues related to environmental protection from the impact of motor transport and that comprehensive evaluation of the harmful impact of motor transport will be helpful in tackling this problem.

\section{References}

[1] AHLVIK P., BRANDBERG Å.: Well-to-Wheel efficiency for alternative fuels from natural gas or biomass. A report for the Swedish National Road Administration, EcoTraffic, 2001.

[2] BARNETT M. O.: Biofuels and greenhouse gas emissions: green or red? Environmental Science \& Technology, 44, 2010, pp. 5330-5331.

[3] BRINKMAN N., WANG M., WEBER T., DARLINGTON T.: Well-to-Wheels Analysis of Advanced Fuel/Vehicle Systems - A North American Study of Energy Use, Greenhouse Gas Emissions, and Criteria Pollutant Emissions. May, 2005.

[4] CHŁOPEK Z., GIS W., WAŚKIEWICZ ].: Zastosowanie biogazu do zasilania silników autobusów miejskich. Rozdział W monografii "Energia niekonwencjonalne i zagospodarowanie odpadów" (Biogas fuelling of city bus engines. A chapter in a monograph "Unconventional energy and waste management). Lublin 2010, pp. 103-116.

[5] CHŁOPEK Z.: Bilansowanie emisji zanieczyszczeń z silników autobusów miejskich (Summing up of pollutants emitted by city bus engines). Transport Samochodowy 3/2009, pp. 55-70.

[6] CHŁOPEK Z.: Ekologiczne i ekonomiczne aspekty eksploatacji silników o zapłonie samoczynnym na paliwo bioetanolowe (Environmental and economic aspects of the operation of diesel engines fired with bioethanol fuel). Transport Samochodowy 2/2008, pp. 37-50. 
[7] CHŁOPEK Z.: Pojazdy samochodowe. Ochrona środowiska naturalnego (Automotive vehicles. Environmental protection). WKt, Warszawa 2002.

[8] CHŁOPEK Z.: Zastosowanie biopaliw $w$ transporcie (The use of biofuels in transport). Scientific Conference "Transport 2008," Lublin, 7 March 2008.

[9] Energy Independence Now: How do Hydrogen Fuel Cell Vehicles Compare in Terms of Emissions and Energy Use? A Well-to-Wheel Analysis.

[10] EPA Lifecycle Analysis of Greenhouse Gas Emissions from Renewable Fuels. U.S. Environmental Protection Agency, Washington, DC, 2010.

[11] FRISCHKNECHT R., STEINER R., BRAUNSCHWEIG A., EGLI N., HILDESHEIMER G.: Swiss Ecological Scarcity Method: The New Version 2006. http://www.esu-services.ch/download/Frischknecht-2006-EcologicalScarcity-Paper. pdf.

[12] http://www.pre.nl/eco-indicator99/.

[13] Napędy hybrydowe, ogniwa paliwowe i paliwa alternatywne (Hybrid propulsion systems, fuel cells, and alternative fuels). Technical Guidebook BOSCH. WKt, Warszawa 2010.

[14] SCHARLEMANN, J. P. W., LAURANCE, W. F.: How Green Are Biofuels? Science, 319, 2008, pp. 43-44.

[15] SITNIK L. J.: Ekopaliwa silnikowe (Motor ecofuels). Oficyna Wydawnicza Politechniki Wrocławskiej (Publishing House of the Wrocław University of Technology), Wrocław 2004.

[16] The Eco-indicator 99. A damage oriented method for Life Cycle Impact Assessment. Methodology Report. Pre Consultants B. V. Amersfoort, 2001.

[17] UNNASCH S.: Alcohol Fuels from Biomass: Well-to-Wheel Energy Balance. Proceedings of the 15th International Symposium on Alcohol Fuels (ISAF), San Diego, California, United States, 26-28 September 2005.

[18] Well-to-Wheels analysis of future automotive fuels and powertrains in the European context. WELL-to-WHEELS Report, Version 2c. EUCAR/CONCAWE/JRC, March 2007.

[19] ZAH R., BÖNI H., GAUCH M., HISCHIER R, LEHMANN M., WÄGER P.: Ökobilanz von Energieprodukten: Ökologische Bewertung von Biotreibstoffen. EMPA, St. Gallen, Switzerland, 2007. 


\title{
KOMPLEKSOWA OCENA ZAGROŻENIA ŚRODOWISKA PRZEZ EKSPLOATACJE, POJAZDÓW SAMOCHODOWYCH
}

\author{
ZDZISŁAW CHŁOPEK', JAKUB LASOCKI² \\ Politechnika Warszawska
}

\section{Streszczenie}

W pracy przedstawiono poglądy na temat kompleksowej oceny zagrożenia środowiska przez eksploatację pojazdów samochodowych. Przedstawiono metody analizy emisji zanieczyszczeń szkodliwych dla środowiska oraz nakładów energetycznych na etapach wytwarzania i dystrybucji nośników energii (od źródła pozyskiwania nośnika energii do zbiornika paliwa Well-to-Tank, w skrócie WtT) oraz użytkowania pojazdów (od zbiornika paliwa do koła pojazdu Tank-to-Wheel, w skrócie TtW). Przeanalizowano wyniki badań zgodnie z procedurami Eco-inicator 99 oraz szwajcarskiej metody ekologicznego deficytu (ang. Swiss Ecological Scarcity Method), nazywanej inaczej metodą Ecoscarcity lub UBP'06. W podsumowaniu autorzy dokonali krytyki istniejących metod kompleksowej oceny szkodliwości motoryzacji dla środowiska i zaproponowali oryginalny system wskaźników, charakteryzujących efekty energetyczne i ekologiczne ze względu na emisję zanieczyszczeń, związane z motoryzacją na etapach wytwarzania i dystrybucji nośników energii oraz użytkowania pojazdów samochodowych.

Słowa kluczowe: motoryzacja, emisja zanieczyszczeń, analiza Well-to-Wheel, paliwa niekonwencjonalne.

\section{Wstęp}

Powszechność i masowość motoryzacji sprawiają, że społeczne odczucie jej oddziaływania na środowisko daleko przekracza racjonalny zakres. Jest to jednak w pewnym sensie uzasadnione, gdyż intuicyjnie nawet odczuwamy na każdym kroku, szczególnie w aglomeracjach miejskich oraz terenach zajmowanych przez trasy komunikacyjne, uciążliwość ekologiczną motoryzacji. Potrzeba oceny zagrożenia środowiska przez motoryzację jest bezdyskusyjna, ponieważ w celu racjonalizacji rozwoju motoryzacji, niezbędnej do funkcjonowania społeczeństwa, konieczne są narzędzia nie tylko jakościowego, ale i ilościowego rozpoznania ekologicznych niebezpieczeństw związanych z tym rodzajem aktywności ludzi. Jest to zadanie tym bardziej trudne, że nie sposób postawić jednoznacznych

'Politechnika Warszawska, Wydział Samochodów i Maszyn Roboczych, Instytut Pojazdów, ul. Narbutta 84, 02-524 Warszawa, zchlopek@simr.pw.edu.pl, tel. 222348559

${ }^{2}$ Politechnika Warszawska, Wydział Samochodów i Maszyn Roboczych, ul. Narbutta 84

02-524 Warszawa, jakub.lasocki@gmail.com, tel. 511092733 
granic w obszarach działalności ludzi, związanej bezpośrednio i pośrednio, bliżej i dalej z motoryzacją. Podmiotami oddziaływania na środowisko, związanymi z motoryzacją są przede wszystkim pojazdy samochodowe, ale także ich wytwórnie oraz infrastruktura obsługowa i infrastruktura ruchu drogowego. Ważne miejsce wśród podmiotów oddziaływania motoryzacji na środowisko zajmują materiały eksploatacyjne, szczególnie paliwa, i ich wytwórnie. W dalszej kolejności można wymienić przemysł wydobywczy, energetyczny itd. Wyraźnego końca na tej liście praktycznie nie ma. Również rodzaje oddziaływania motoryzacji na środowisko są bardzo złożone, poczynając od wypadków drogowych, poprzez emisję zanieczyszczeń, promieniowania elektromagnetycznego i hałasu oraz powodowanie drgań, wycieki materiałów eksploatacyjnych, aż do zajmowania terenu i degradacji krajobrazu.

Widać zatem, że u podstaw kompleksowej oceny oddziaływania motoryzacji na środowisko muszą się znajdować jasne ograniczenia i konieczne jest przyjmowanie pewnych założeń, umożliwiających w ogóle dokonanie takiej oceny. Najczęściej ogranicza się ocenę tylko do emisji zanieczyszczeń szkodliwych dla środowiska ludzi, w szczególności dla ich zdrowia. Bardzo często ogranicza się te badania wyłącznie do warunków użytkowania samochodów. Nawet przy tak dużych ograniczeniach są poważne problemy przyporządkowania poszczególnym zanieczyszczeniom pewnych wag szkodliwości, co umożliwiłoby porównanie rozpatrywanych sytuacji. Przykładem próby rozwiązania tego problemu jest zaproponowany w dyrektywie 2009/33/WE w sprawie promowania ekologicznie czystych i energooszczędnych pojazdów algorytm przypisywania poszczególnym wybranym substancjom kosztów obciążenia środowiska. Kolejnym poważnym zagadnieniem jest przyjęcie porównywalnych modeli stanów pracy silników spalinowych, reprezentatywnych dla ich użytkowania w samochodach. Jest to problem tym bardziej ważny, że - jak wiadomo - emisja zanieczyszczeń jest bardzo wrażliwa na stany pracy silników spalinowych, szczególnie na występowanie stanów dynamicznych.

W związku z rozpowszechnianiem się problemu zastosowania odnawialnych nośników energii aktualna okazuje się potrzeba oceny emisji zanieczyszczeń i nakładów energetycznych z uwzględnieniem wytwarzania i dystrybucji tych nośników. Bardzo często społeczne zainteresowanie ogranicza się $w$ tych wypadkach jedynie do emisji gazów cieplarnianych, a szczególnie dwutlenku węgla, co wynika bardziej z presji propagandowej niż $\mathrm{z}$ racjonalnych przesłanek. Zaniedbywanie $w$ takich rozważaniach zagrożenia bezpośrednio niebezpiecznego dla zdrowia ludzi jest przejawem nie tylko niefrasobliwości niekompetentnych ideologów, ale i nieodpowiedzialności ludzi, którym społeczeństwa w naiwny sposób zaufały.

Kompleksowa ocena emisji zanieczyszczeń i nakładów energii związanych z wytwarzaniem, dystrybucją i użytkowaniem nośników energii w pojazdach jest przedmiotem rozważań przedstawianych $w$ niniejszej pracy. Posłużono się w tym celu przykładami głównie z Europy Zachodniej, przede wszystkim ze Szwajcarii. Korzystając z tych przykładów autorzy starają się przekonać o znacznej względności wyników tych analiz i zachęcają do ostrożności w prowadzeniu takich badań. 
Przytoczone metody badań są obciążone znaczną słabością formalną. Z tego powodu autorzy starają się, w miarę możliwości, unikać występujących w oryginalnych materiałach nieformalności i niezręczności, m.in. tłumacząc na język polski występujące w języku angielskim tak typowe dla cywilizacji zachodniej skomercjalizowane określenia, wadliwe językowo i nieprzystające nauce. Do najważniejszych spośród niezręcznych i wadliwych terminów należy „życie" odnoszone do przedmiotów. Powszechnie występujące określenia typu "cykl życia pojazdów" są przejawem marketingowej komercjalizacji języka. Autorzy konsekwentnie używają określenia „istnienie pojazdu", bolejąc nad tym, że nie udało im się znaleźć właściwego określenia w miejsce "cyklu", bowiem - w istocie - istnienie pojazdu nie ma charakteru cyklicznego. Być może lepsze byłoby określenie „czas istnienia pojazdu” zamiast "cykl istnienia pojazdu". Istnieją również poważne trudności w przyswojeniu polskiej nauce niesformalizowanych w oryginalnych źródłach pojęć, takich jak np. „strumienie oddziaływania", które mają być może dużą wartość literacką, ale na pewno nie naukową.

Mimo tych trudności w kompleksowym ocenianiu szkodliwości motoryzacji dla środowiska autorzy są świadomi konieczności podejmowania takich działach, upatrując mniejsze ryzyko w stosowaniu w ocenach minimalistycznych rozwiązań, np. w postaci znacznego ograniczenia ogólności prowadzonych analiz.

\section{Założenia do analizy zagrożenia środowiska w cyklu istnienia pojazdu samochodowego}

Bilansowanie zagrożeń środowiska w całym umownym cyklu istnienia pojazdu samochodowego odbywa się najczęściej przy użyciu określonej metody i odpowiedniego oprogramowania (ze względu na dużą ilość danych i niekiedy skomplikowane algorytmy obliczeniowe). Jedną z najczęściej stosowanych metod jest analiza "Well-to-Wheel" (WtW) [1, 3, 9, 10, 17-19], której nazwę można przetłumaczyć jako „od źródła (pozyskiwania nośnika energii) do koła (pojazdu)" [5, 8]. Obszarem zastosowań analizy Well-to-Wheel jest wyznaczanie emisji zanieczyszczeń (najczęściej gazów cieplarnianych) i zużycia energii związanego z zastosowaniem różnych rodzajów paliw oraz odpowiadających im możliwych napędów pojazdów. Uwzględnia się przy tym cały umowny cykl istnienia paliwa obejmujący pozyskiwanie nośników energii pierwotnej, przetwarzanie ich na nośniki energii wykorzystywane do napędzania pojazdu, transport i dystrybucję oraz końcową emisję zanieczyszczeń z pojazdu w trakcie jego eksploatacji. W praktyce analizę Well-to-Wheel rozpatruje się w dwóch etapach (rysunek 1) [1, 3, 5, 10, 13, 15, 17, 18]:

- od źródła pozyskiwania nośnika energii do zbiornika paliwa (Well-to-Tank - WtT),

- od zbiornika paliwa do koła pojazdu (Tank-to-Wheel - TtW).

Końcowym wynikiem jest suma zużycia energii i suma emisji zanieczyszczeń (gazów cieplarnianych) wyznaczone w obydwu etapach. 

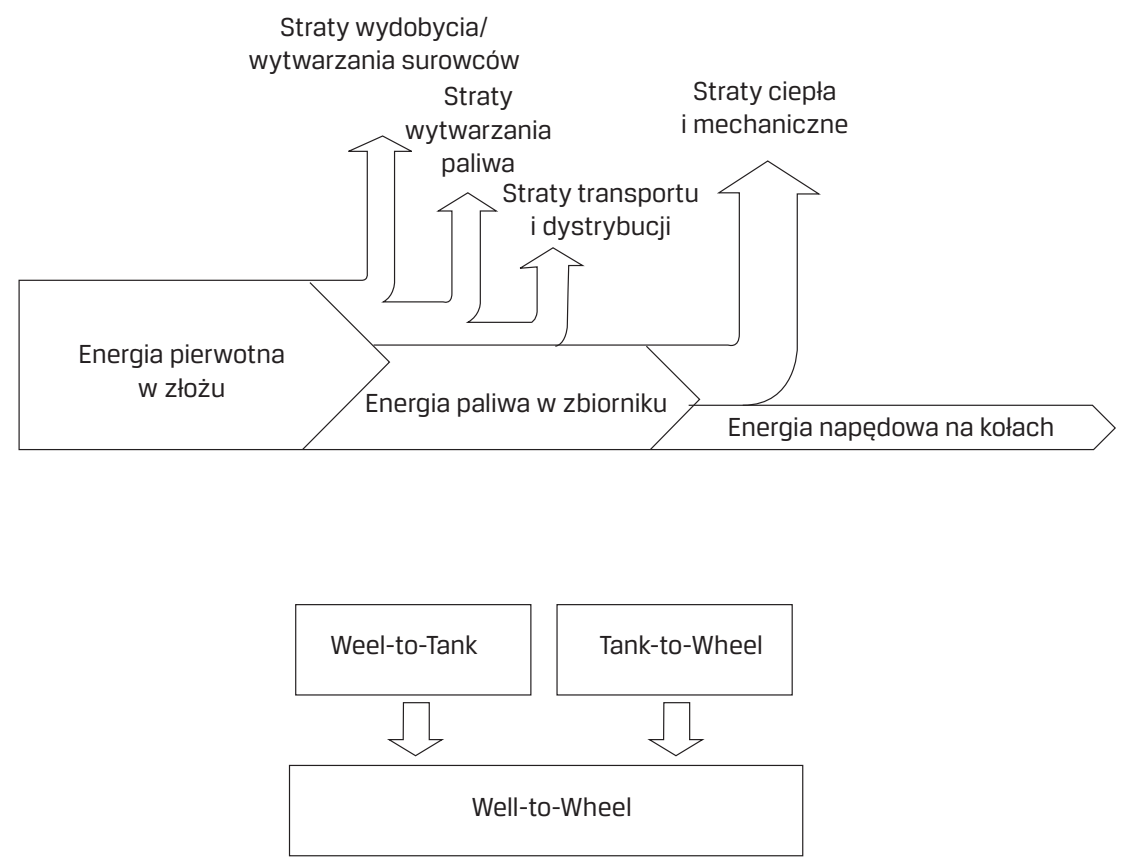

Rys. 1. Schemat analizy Well-to-Wheel

Pierwsza część analizy - etap Well-to-Tank - obejmuje procesy związane z przygotowaniem paliwa, a więc wytwarzanie lub wydobycie surowców (nośników energii pierwotnej), przeróbkę surowców, transport paliwa i jego rozdział, aż do zbiornika paliwa w pojeździe. Można określić sprawność tego etapu, zwaną sprawnością gotowości (tabela 1) [13] - jest to iloraz wartości ilości energii zawartej w gotowym paliwie (po odjęciu energii potrzebnej do jego przygotowania) i wartości ilości energii pierwotnej nośnika w postaci nieprzetworzonej. Straty energii i wielkości emisji zanieczyszczeń wynikające z przygotowania paliwa zależą nie tylko od jego rodzaju, lecz także od przyjętej metody produkcji i zastosowanego substratu. Jeżeli bowiem dla danego paliwa istnieje kilka możliwych technologii wytwarzania (na przykład wodór można otrzymywać poprzez reforming parowy metanu, gazyfikację węgla lub biomasy, pirolizę biomasy lub elektrolizę wody), to końcowy bilans energii i emisji będzie zależał od tego, którą z technologii poddano analizie. 
Tabela 1. Względne straty energii występujące podczas cyklu przygotowania oleju napędowego, benzyny silnikowej, sprężonego gazu ziemnego (CNG) i sprężonego wodoru oraz łączna sprawność przygotowania tych paliw (na podstawie [13]).

\begin{tabular}{|l|c|c|c|c|}
\hline Działania powodujące straty energii & $\begin{array}{c}\text { Oleje } \\
\text { napędowe }\end{array}$ & $\begin{array}{c}\text { Benzyny } \\
\text { silnikowe }\end{array}$ & $\begin{array}{c}\text { Gaz ziemny } \\
\text { (CNG) }\end{array}$ & Wodór \\
\hline $\begin{array}{l}\text { Wydobycie, wstępne przygotowanie } \\
\text { i transport daleki }\end{array}$ & 0,03 & 0,03 & 0,01 & 0,1 \\
\hline Przeróbka - rafinacja/reforming par & 0,06 & 0,08 & 0 & 0,2 \\
\hline $\begin{array}{l}\text { Dystrybucja wewnątrzkrajowa } \\
\text { (stacje szybkiego tankowania dla } \\
\text { gazu ziemnego i wodoru) }\end{array}$ & 0,02 & 0,02 & 0,12 & 0,17 \\
\hline $\begin{array}{l}\text { tączna sprawność przygotowania } \\
\text { (po uwzględnieniu wartości } \\
\text { energetycznej paliwa) }\end{array}$ & 0,89 & 0,86 & 0,8 & 0,6 \\
\hline
\end{tabular}

Opublikowano wiele opracowań literaturowych oraz obszernych raportów prezentujących nie tylko wyniki analiz Well-to-Wheel, lecz również rodzaje czynników uwzględniane w obliczeniach. W niniejszym artykule, na podstawie prac [1, 2, 3, 9, 10, 13, 14, 17-19], omówiono najważniejsze czynniki mające wpływ na ocenę paliwa na etapie jego przygotowania.

W analizie ciągnionej biopaliw pozyskiwanych z roślin energetycznych należy wziąć pod uwagę straty energii i zanieczyszczenie środowiska wynikające z prowadzenia uprawy. Uwzględnia się m.in. zużycie oleju napędowego w maszynach rolniczych, stosowanie nawozów azotowych, ilość wykorzystanej wody oraz umowne wartości emisji związane ze zmianą sposobu zagospodarowania terenów przeznaczonych pod uprawy roślin do produkcji biopaliw. Czynniki te można pominąć w przypadku paliw uzyskiwanych z biomasy odpadowej, przyjmując ich wartość równą zeru. Szczególnie cenna jest możliwość zmniejszenia ilości wyemitowanego dwutlenku węgla przez wzgląd na asymilację tego gazu przez rośliny podczas wzrostu - w bilansie końcowym wielkość ta przyjmuje znak ujemny. Istotny aspekt stanowi również sposób wykorzystania produktów ubocznych powstających podczas przerobu biomasy. Część z nich może zostać zużyta w innych gałęziach przemysłu, np. gliceryna z produkcji biodiesla znajduje zastosowanie w przemyśle farmaceutycznym, kosmetycznym, papierniczym i innych, a przy produkcji bioetanolu ze zboża otrzymuje się karmę dla zwierząt. Takie produkty uboczne zastępują produkty wytwarzane w konwencjonalny sposób, przyczyniając się do zmniejszenia zużycia energii i ograniczenia emisji zanieczyszczeń. Emisję powstałą podczas produkcji dzieli się zwykle pomiędzy paliwo i produkty uboczne, proporcjonalnie do ich zawartości energii. Dużo kontrowersji wzbudza wykorzystywanie do produkcji biopaliw substratów, które mogłyby być użyte w innym celu, np. zboże do produkcji żywności i paszy dla zwierząt, trzcina cukrowa do produkcji cukru, czy drewno do uzyskania energii cieplnej. W bilansie energetycznym istnienie tego typu rozwiązania energetycznego traktowane jest jako czynnik negatywny. 
W odróżnieniu od biopaliw, technologia otrzymywania gazu ziemnego jest znacznie mniej skomplikowana. Głównymi czynnikami, jakie należy uwzględnić na etapie od źródła pozyskiwania do zbiornika paliwa są: wydobycie, transport rurociągami i sprężanie (CNG) lub skraplanie (LNG) na stacji paliw.

Najistotniejsze znaczenie $w$ analizie przygotowania wodoru ma zastosowana metoda produkcji. W przypadku reformingu parowego gazu ziemnego, który jest obecnie najbardziej rozpowszechniony, rozpatruje się zwłaszcza transport gazu ziemnego, sam proces reformowania parowego metanu i sprężanie wodoru na stacji paliw. Jeżeli natomiast wodór powstał w wyniku elektrolizy wody, w bilansie emisji i energetycznym ważne jest ustalenie pochodzenia energii elektrycznej. Wodór uznaje się za „czysty" (biowodór) jeśli został uzyskany przy wykorzystaniu energii elektrycznej ze źródeł odnawialnych (np. elektrownie wiatrowe lub słoneczne). W przeciwnym razie emisję towarzyszącą pozyskaniu energii elektrycznej należy dołączyć do bilansu emisji wodoru.

Paliwa konwencjonalne charakteryzują się znacznym zapotrzebowaniem energii na wydobycie i transport ropy naftowej do rafinerii, następnie na wytworzenie benzyny lub oleju napędowego oraz transport do odbiorcy końcowego. Często wyniki bilansu dla paliw ropopochodnych $w$ analizie Well-to-Wheel traktuje się jako poziom odniesienia do porównania właściwości ekologicznych różnych rodzajów paliw niekonwencjonalnych.

Wymienione przykłady danych wykorzystywanych w analizach etapu Well-to-Tank mają jedynie charakter orientacyjny. W rzeczywistości prawie każda z wymienionych operacji może być realizowana na kilka różnych sposobów, np. transport wodny, szynowy i kołowy wiążą się z innymi wydatkami energetycznymi i emisjami zanieczyszczeń. Ocena danego paliwa jest zatem bardzo wrażliwa na przyjęte założenia.

W drugim etapie - od zbiornika paliwa do koła pojazdu (Tank-to-Wheel) - badana jest emisja zanieczyszczeń i zużycie paliwa przez pojazd. Decydujące znaczenie w tej części analizy ma rodzaj zastosowanego paliwa, rodzaj układu oczyszczania spalin oraz ogólna sprawność układu napędowego [13] - największa dla ogniw paliwowych, mniejsza dla silników o zapłonie samoczynnym i najmniejsza dla silników o zapłonie iskrowym (hybrydyzacja z zastosowaniem silnika elektrycznego pozwala na dodatkowy wzrost sprawności ogólnej) [1].

Badania wykonuje się zazwyczaj w warunkach laboratoryjnych na hamowni podwoziowej (obejmują wtedy cały pojazd) lub na hamowni silnikowej (obejmują wówczas sam silnik) z wykorzystaniem różnego rodzaju testów, zarówno statycznych, jak i dynamicznych. Zazwyczaj wykorzystuje się testy stosowane w procedurach homologacyjnych, co w zasadzie nie upoważnia do formułowania wniosków o właściwościach silników w warunkach ich rzeczywistego użytkowania. Jest to najpoważniejsza słabość powszechnie stosowanych metod analiz oddziaływania motoryzacji na środowisko. Co prawda stosowanie do badań silników testów homologacyjnych umożliwia analizy porównawcze efektów energetycznych i emisji zanieczyszczeń, ale formułowanie sądów o inwentaryzacji energii i emisji zanieczyszczeń, co jest powszechną praktyką, zarówno wśród specjalistów, jak i wśród ludzi czynu: propagandystów i polityków, jest już zupełnie niedopuszczalne. 
Niezależnie od zastrzeżeń metodologicznych - przynajmniej w zamyśle badaczy - ostatecznym wynikiem analizy Well-to-Wheel jest suma nakładów energii i łączna masa zanieczyszczeń wyemitowanych na obydwu etapach: przygotowania paliwa (Well-to-Tank) i jego wykorzystania w pojeździe (Tank-to-Wheel).

Na podstawie bilansu energetycznego określa się ilość energii potrzebną do przygotowania paliwa zużytego przez pojazd na pokonanie drogi o jednostkowej długości (jednostki: $\mathrm{MJ} / \mathrm{km}, \mathrm{MJ} / \mathrm{mi}$ ). Zwykle podaje się też inne wskaźniki, np. zdefiniowaną wcześniej ogólną sprawność cyklu Well-to-Wheel [1, 3, 9, 10, 13, 17-19].

Bilansując emisje gazów cieplarnianych (dwutlenku węgla oraz m.in. metanu i podtlenku azotu) dla całego cyklu, sprowadza się je do ekwiwalentnej emisji dwutlenku węgla $\mathrm{CO}_{2 \mathrm{eq}}$ a następnie sumuje. Poszczególnym gazom przypisywane są odpowiednie wartości równoważnika dwutlenku węgla, proporcjonalnie do ich potencjalnego udziału w nasilaniu rozwoju zjawiska cieplarnianego (dane liczbowe zaczerpnięto z dyrektywy 2009/28/WE):

- dwutlenek węgla - 1 ,

- podtlenek azotu - 296,

- metan - 23 .

Postępowanie takie ułatwia obliczenia emisji gazów cieplarnianych oraz końcową interpretację i porównanie wyników. Ostatecznie emisję gazów cieplarnianych charakteryzuje się jako emisję drogową ekwiwalentnego dwutlenku węgla, tzn. wartość masy ekwiwalentnego dwutlenku węgla wyemitowanego podczas przygotowania paliwa i jego wykorzystania w pojeździe odniesioną do drogi przebytej przez ten pojazd (jednostki: g/km, g/mi) lub jako energetyczny wskaźnik emisji ekwiwalentnego dwutlenku węgla, czyli wartość masy ekwiwalentnego dwutlenku węgla wyemitowanego podczas przygotowania i spalenia paliwa zawierającego $1 \mathrm{MJ}$ energii (jednostka: g/MJ) [1, 3, 9, 10, 13, 17-19].

Szczegółowe zasady obliczania całkowitej emisji gazów cieplarnianych na etapie Well-toTank dla różnego rodzaju biopaliw używanych w krajach Unii Europejskiej określa zaimplementowana przez Polskę Dyrektywa Parlamentu Europejskiego i Rady 2009/28/WE z dnia 23 kwietnia 2009 r., promująca stosowanie energii ze źródeł odnawialnych. Postanowienia dyrektywy stanowią podstawę oceny, czy każde z państw członkowskich Unii Europejskiej zdoła osiągnąć zakładany minimalny udział energii ze źródeł odnawialnych w końcowym zużyciu energii brutto w 2020 r. (tzw. narodowy cel wskaźnikowy). Zgodnie z dyrektywą, całkowity energetyczny wskaźnik emisji ekwiwalentnego dwutlenku węgla (inaczej: gazów cieplarnianych) wyznacza się na podstawie wzoru:

$$
W E=W E_{e c}+W E_{l}+W E_{p}+W E_{t d}+W E_{u}-W E_{s c a}-W E_{c c s}-W E_{c c r}-W E_{e e}
$$

gdzie:

$\mathrm{WE}_{\mathrm{ec}}$ - energetyczny wskaźnik emisji spowodowanej wydobyciem lub uprawą surowców, 

$\mathrm{WE}_{1}$ - energetyczny wskaźnik emisji w ujęciu rocznym spowodowanej zmianami ilości pierwiastka węgla w związku ze zmianą sposobu użytkowania gruntów,
$\mathrm{WE}_{\mathrm{p}}$ - energetyczny wskaźnik emisji spowodowanej procesami technologicznymi,
$\mathrm{WE}_{\mathrm{td}}$ - energetyczny wskaźnik emisji spowodowanej transportem i dystrybucją,
$\mathrm{WE}_{\mathrm{u}}$ - energetyczny wskaźnik emisji spowodowanej stosowanym paliwem,
$\mathrm{WE}_{\text {sca }}$ - ograniczenie energetycznego wskaźnika emisji spowodowane akumulacją pierwiastka węgla w glebie dzięki lepszej gospodarce rolnej,
$\mathrm{WE}_{\text {ccs }}$ - ograniczenie energetycznego wskaźnika emisji spowodowane wychwytywaniem dwutlenku węgla i jego składowaniu w głębokich strukturach geologicznych,
$\mathrm{WE}_{\text {ccr }}$ - ograniczenie energetycznego wskaźnika emisji spowodowane wychwytywaniem dwutlenku węgla i jego zastępowaniem,
$W_{\text {ee }}$ - ograniczenie energetycznego wskaźnika emisji dzięki zwiększonej produkcji energii elektrycznej w wyniku kogeneracji.

Definicje wielkości uwzględnionych w powyższym wzorze wyszczególniono w dyrektywie, podano tam również ich wartości albo sposób obliczania w zależności od rodzaju biopaliwa, metody jego otrzymywania i surowca wykorzystywanego do produkcji.

Przykładowe wyniki obliczeń całkowitego energetycznego wskaźnika emisji dwutlenku węgla spowodowanej uprawą roślin, produkcją (z wykorzystaniem różnych technologii), transportem i dystrybucją wybranych biopaliw przedstawiono w sposób zbiorczy na rysunku 2.

Niejednokrotnie poddając analizie zagrożenia środowiska spowodowane eksploatacją pojazdów samochodowych, poza całkowitą emisją i zużyciem energii, uwzględnia się także inne dodatkowe wskaźniki porównawcze. Niektóre z nich zestawiają wpływ pojazdu na środowisko na kilku różnych płaszczyznach oddziaływania, dążąc do oceny jakościowej. Przykładem jest tzw. „ekowskaźnik" (ang. ecoindicator), wyznaczany w metodzie Ecoindicator $99[12,16]$, który łączy w sobie ocenę oddziaływania na środowisko w trzech obszarach wpływu:

- zdrowie człowieka,

- jakość ekosystemu,

- surowce.

Szkodliwość dla zdrowia człowieka jest wyrażona w tej metodzie indeksem DALY (ang. Disability-Adjusted Life Year - rok życia skorygowany o niepełnosprawność), który jest jednostką miary oddziaływania choroby na człowieka zarówno pod względem czasu życia utraconego z powodu przedwczesnego zgonu (umieralność), jak i czasu przeżytego w stanie niepełnosprawności (chorobowość). Indeks ten wykorzystuje się powszechnie w ekonomii zdrowia do określenia stanu zdrowia danej populacji (stosowany jest m.in. 


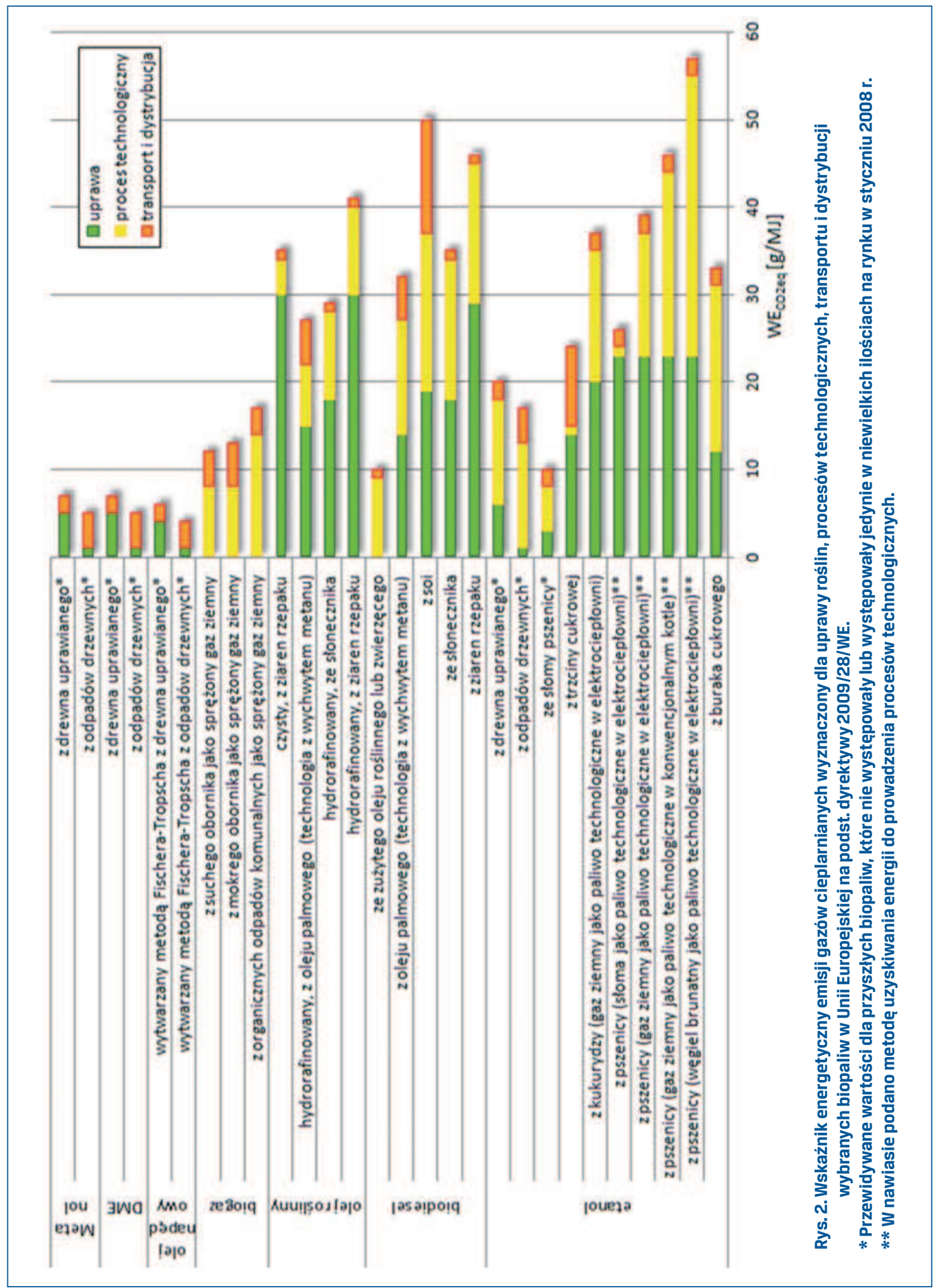


przez Światową Organizację Zdrowia - WHO). W metodzie Eco-inicator 99 stworzono modele uwzględniające schorzenia układu oddechowego, nowotwory, skutki zmian klimatu, uszkodzenia warstwy ozonowej (powodujące m.in. raka skóry i zaćmę) oraz szkodliwość promieniowania jonizującego. Mierzy się przy tym m.in. ekspozycję na zanieczyszczenia oraz ich imisję.

Szkodliwość dla jakości ekosystemu określa się jako udział gatunków zanikających na danym obszarze w wyniku oddziaływania pojazdów (lub procesu produkcji paliwa) na środowisko. Bierze się pod uwagę m.in. zakwaszenie i eutrofizację wody i gleby, zmianę sposobu użytkowania gruntów (np. deforestacja) oraz tzw. ekotoksyczność, zdefiniowaną tu jako udział gatunków występujących na danym obszarze w określonym przedziale czasu, żyjących pod wpływem stresu toksycznego PAF (ang. Potentially Affected Fraction) [16].

Trzeci obszar wpływu - zużycie surowców jest oceniane przez wzgląd na jakość pozostałych do wydobycia złóż surowców, w tym paliw ropopochodnych. Określa się je jako nadwyżkę energii, jaką należy włożyć w eksploatację $1 \mathrm{Mg}$ surowca (jednostka MJ/Mg). W niektórych przypadkach rozpatruje się także skalę wydobycia innych pierwiastków i związków.

Końcowa postać ekowskaźnika to wartość, która jest sumą wartości uzyskanych dla trzech obszarów wpływu z uwzględnieniem odpowiednich wag. Metoda Eco-indicator 99 pozwala ponadto wybrać jedną z trzech tzw. perspektyw interpretacyjnych: hierarchiczną, egalitarną lub indywidualną, które determinują wagi każdego z trzech obszarów wpływu. Jako domyślną stosuje się perspektywę hierarchiczną, w której zdrowie człowieka oraz jakość ekosystemu wpływają na wynik końcowy w udziale po 40\%, zaś zużycie surowców tylko w $20 \%$. Inaczej jest w przypadku perspektywy egalitarnej, gdzie jakość ekosystemu ma największą wage - $50 \%$, następnie zdrowie człowieka - $30 \%$ i surowce $-20 \%$. W podejściu indywidualnym dominuje natomiast zdrowie człowieka z wagą 55\%, potem jakość ekosystemu - $25 \%$ i na końcu surowce - $20 \%[12,16]$.

Na podstawie metody Eco-indicator 99 obliczono ponad 200 ekowskaźników dla najczęściej używanych materiałów i procesów. Stworzono także komputerowe bazy danych wspomagające ocenę zagrożenia środowiska w oparciu o istniejące ekowskaźniki oraz umożliwiające obliczanie wartości nowych (np. SimaPro [12]).

Nieco inne podejście reprezentuje szwajcarska metoda ekologicznego deficytu (ang. Swiss Ecological Scarcity Method) [11], nazywana niekiedy metodą Ecoscarcity lub UBP'O6 (z niem. Umweltbelastungspunkte). Podobnie jak w przypadku metody Eco-indicator 99, uwzględnia ona kilka obszarów wpływu badanego produktu czy procesu (np. eksploatacji pojazdu samochodowego) na środowisko. Brana jest pod uwagę głównie emisja zanieczyszczeń (czynniki takie jak: zakwaszanie i eutrofizacja, zmniejszanie warstwy ozonowej itd.) oraz wykorzystanie surowców naturalnych. Unikatowość metody polega na wyznaczaniu różnicy między aktualnym obciążeniem środowiska na danym obszarze - tzw. aktualnym strumieniem oddziaływania (ang. current flow) i możliwym maksymalnym obciążeniem wynikającym z istniejących ograniczeń legislacyjnych lub celów politycznych 
- tzw. krytycznym strumieniem oddziaływania (ang. critical flow). Pojęcia strumieni oddziaływania nie są sformalizowane, należy zatem je oceniać jako typowy dla komercyjnych nurtów nauki Zachodu sposób barwnego i pompatycznego przedstawiania wyników uprawiania działalności intelektualnej. Można domniemywać, że tzw. strumienie oddziaływania są wielkościami fizycznymi, charakteryzującymi oddziaływanie cywilizacji na środowisko, takimi jak np. imisja zanieczyszczeń, emisja drogowa czy emisja jednostkowa zanieczyszczeń wprowadzanych przez silniki spalinowe. Zgodnie ze szwajcarską metodą wynikiem oceny zagrożenia środowiska jest wskaźnik eco-factor, którego jednostkę zdefiniowano jako tzw. eko-punkt (ang. eco-point, EP) dzielony przez jednostkę charakteryzującą rozpatrywane oddziaływanie na środowisko (w przypadku emisji gazów cieplarnianych jest to EP/g). Wskaźnik eco-factor oblicza się według wzoru [11]:

$$
\text { eco }- \text { factor }=K \cdot \frac{1 \cdot E P}{F_{n}}\left(\frac{F}{F_{k}}\right)^{2} \cdot c
$$

gdzie:

K - współczynnik względnej szkodliwości oddziaływania,

F - aktualny strumień oddziaływania,

$\mathrm{F}_{\mathrm{n}}$ - znormalizowany strumień oddziaływania,

$\mathrm{F}_{\mathrm{k}}$ - krytyczny strumień oddziaływania

c - wartość stała.

Wskaźnik eco-factor można zatem zdefiniować jako miarę potencjalnego zagrożenia środowiska jakie niesie ze sobą dane oddziaływanie. Jego wartość jest tym większa, im bardziej aktualny poziom emisji czy konsumpcji surowców naturalnych przekracza założone limity. Występujący we wzorze współczynnik względnej szkodliwości oddziaływania koryguje wynik rozróżniając substancje o bardziej lub mniej negatywnym wpływie na środowisko (jak w wypadku gazów cieplarnianych). Wartość aktualnego strumienia oddziaływania pochodzi zwykle z najnowszych dostępnych danych statystycznych dla danego obszaru.

Głównymi zaletami szwajcarskiej metody ekologicznego deficytu są: prosty sposób obliczeń oraz bezpośrednie odniesienie do politycznych celów i ograniczeń prawnych obowiązujących w danym regionie bądź kraju. Odróżnia ją to od metod kładących nacisk na bezwzględną ocenę szkód w środowisku (jak np. Eco-indicator 99). Jednak z drugiej strony wskaźniki eco-factor mogą być wyznaczane jedynie dla substancji, dla których istnieją wspomniane limity prawne lub cele polityczne. 


\section{Przykład analizy emisji gazów cieplarnianych w cyklu istnienia pojazdu samochodowego}

Należy podkreślić, że wynik analizy przeprowadzonej metodą Well-to-Wheel silnie zależy od ustalonego przez autorów zakresu badań, w tym od liczby i wagi zastosowanych czynników, przyjętych założeń i uproszczeń, a więc powinien być rozpatrywany wyłącznie z ich uwzględnieniem. Z tego powodu wyniki analiz opublikowane w pracach [1, 3, 10, 14, 17-19] nie zawsze pozostają ze sobą w całkowitej spójności, a niekiedy nawet bywają sprzeczne. Pozycje literaturowe z ostatnich lat, w odniesieniu do starszych, uwzględniają na ogół więcej czynników pośrednich, na przykład emisję dwutlenku węgla związaną ze zmianą sposobu zagospodarowania terenów przeznaczonych pod uprawy roślin do produkcji biopaliw $[2,14,19]$.

Interesujące wyniki badań z wykorzystaniem analizy Well-to-Wheel przedstawiono w pracy [19]. Porównano w niej ekologiczne właściwości paliw nieodnawialnych: benzyny silnikowej, oleju napędowego i gazu ziemnego z właściwościami 26 rodzajów biopaliw produkowanych z wykorzystaniem różnych surowców i technologii dostępnych w Szwajcarii. Analizie poddano pięć umownych procesów wchodzących w skład cyklu istnienia paliwa: uprawę roślin (jeśli występuje), produkcję, transport do stacji paliw, wykorzystanie w pojazdach oraz budowę i utrzymanie infrastruktury. W celu oceny ich oddziaływania na środowisko naturalne zaproponowano koncepcję opartą na dwóch wskaźnikach. Są to:

- emisja gazów cieplarnianych (w postaci ekwiwalentnej emisji dwutlenku węgla),

- całkowity bilans ekologiczny (ökologische Gesamtbilanz).

Wartość całkowitego bilansu ekologicznego obliczono dla każdego paliwa dwiema odmiennymi metodami - szwajcarską metodą ekologicznego deficytu (wskaźnik eco-factor) oraz metodą Eco-indicator 99 (ekowskaźnik) - rysunek 3.

Na rysunku 4 przedstawiono charakterystyki dla wybranych biopaliw we współrzędnych: względny energetyczny wskaźnik emisji gazów cieplarnianych - względny eco-factor, odniesione do wartości dla benzyny. Analiza uzyskanych przez autorów wyników pozwala stwierdzić, że większość z rozważanych biopaliw (21 z 26) ogranicza emisję gazów cieplarnianych o więcej niż 30\% w odniesieniu do emisji odpowiadających benzynom silnikowym. Z drugiej strony prawie połowa biopaliw (12 z 26) charakteryzuje się bardziej szkodliwym oddziaływaniem na środowisko naturalne niż paliwa kopalne. W grupie tej znajdują się biopaliwa produkowane obecnie na największą skalę, tj. bioetanol z kukurydzy (Stany Zjednoczone Ameryki), biodiesel z soi i bioetanol z trzciny cukrowej (Brazylia) oraz biodiesel z oleju palmowego (Malezja). Znacznie lepsze właściwości ekologiczne wykazują biopaliwa wytwarzane z biomasy odpadowej, np. ze zużytego oleju roślinnego, oraz etanol z drewna lub trawy. Uzyskane wyniki uwydatniają różnice pomiędzy korzyściami i stratami związanymi z zastosowaniem poszczególnych biopaliw [14, 19]. 


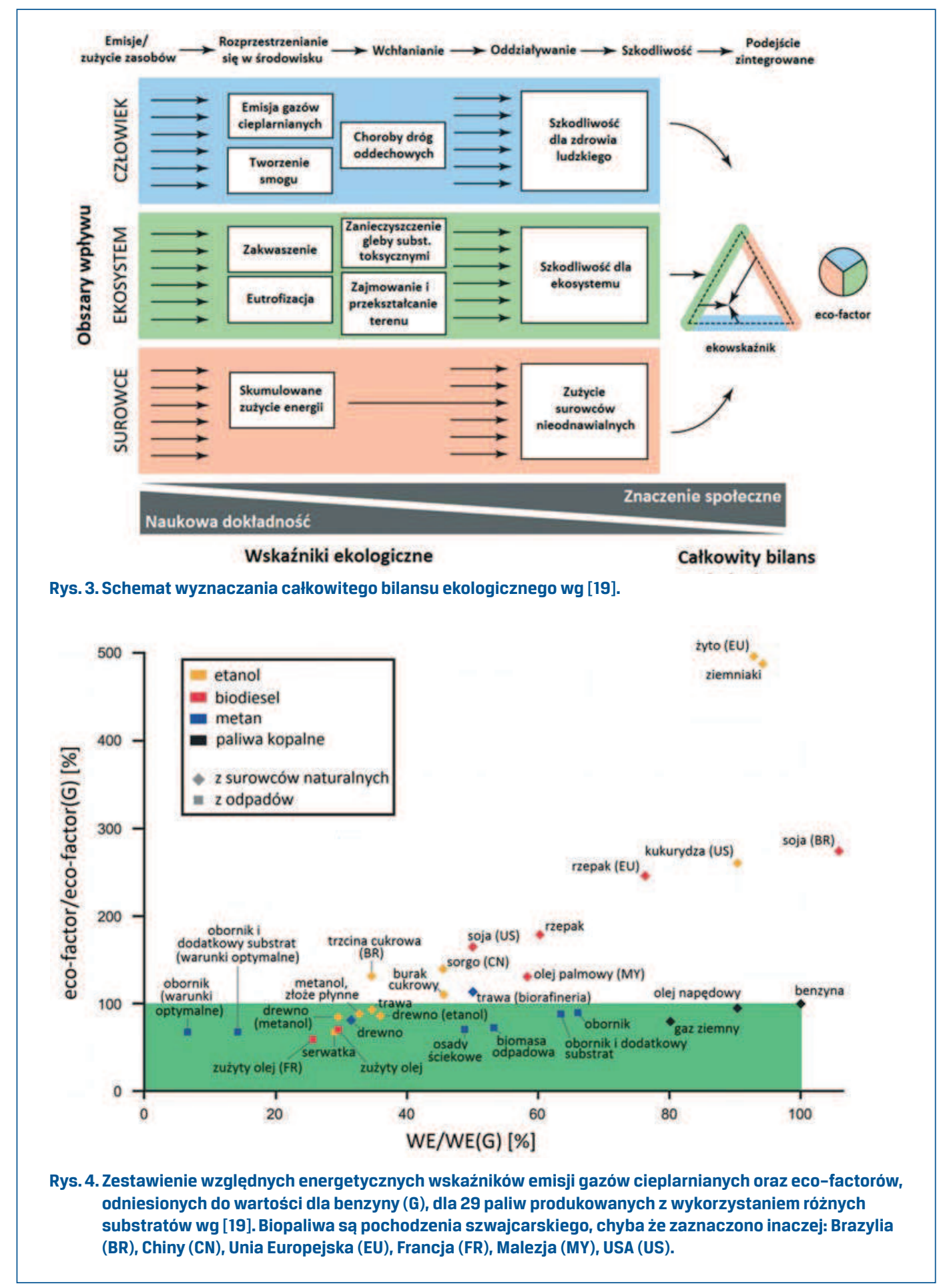


Na rysunkach 5 i 6 przedstawiono emisję drogową gazów cieplarnianych i eco-factory dla kolejnych procesów wchodzących w skład cyklu istnienia rozważanych paliw. Zasadniczo największe wartości obydwu wskaźników (choć nie dla wszystkich paliw) występują podczas uprawy roślin, ze względu na użycie maszyn rolniczych, nawozów i pestycydów oraz innych czynników, takich jak: zakwaszenie gleby i utrata bioróżnorodności terenów, szczególnie w strefach tropikalnych. Proces produkcji jest drugim co do wielkości żródłem emisji gazów cieplarnianych, zaś transport paliwa do szwajcarskich stacji paliw przyczynia się w niewielkim stopniu (mniej niż 10\%) do powstawania emisji i innych zagrożeń środowiska $[14,19]$.

Zaprezentowane wyniki analizy można uznać za atrakcyjne, gdyż obejmują szeroki zakres

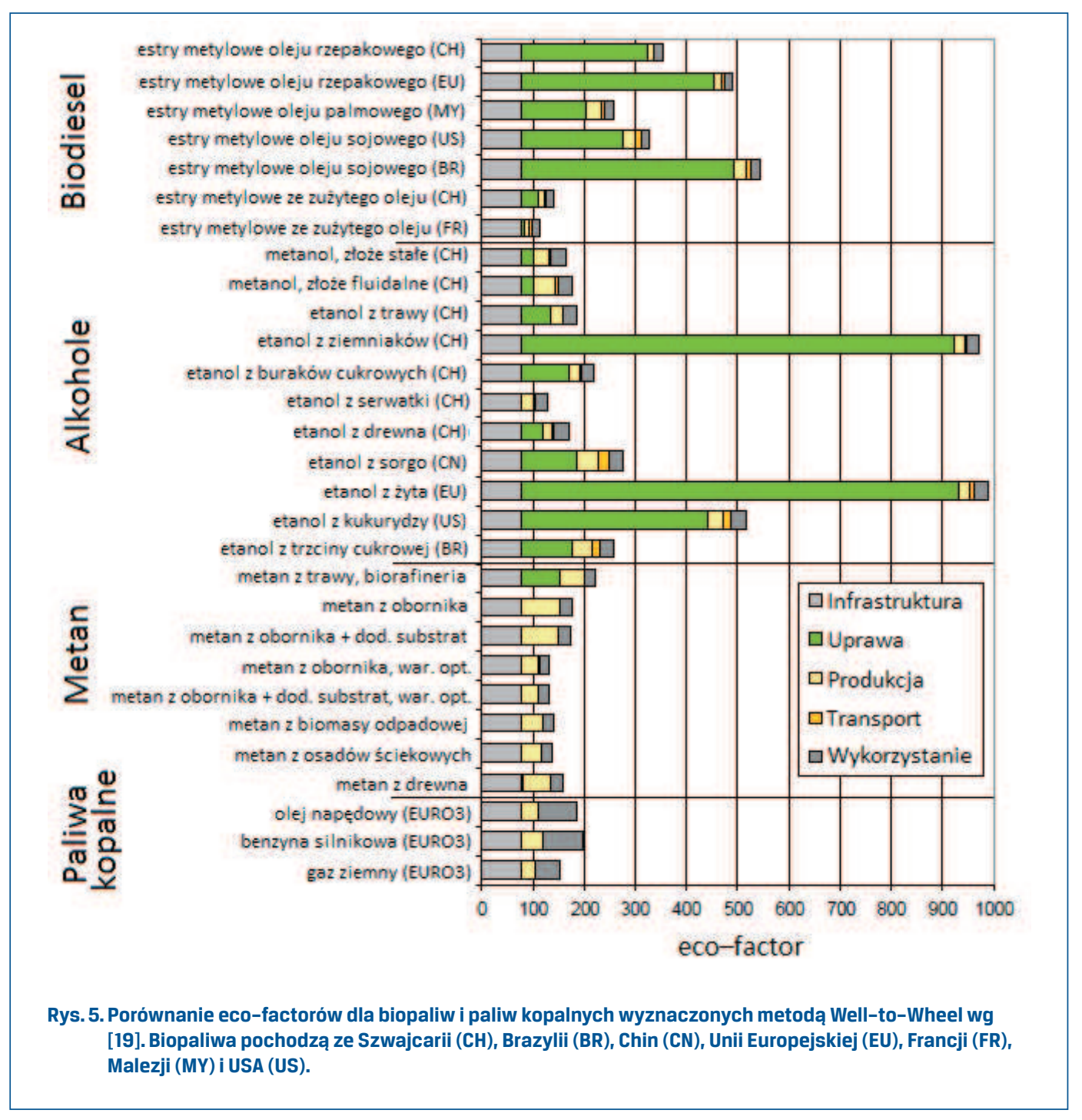


danych wejściowych i wiele rodzajów paliw. Mimo to zastosowana metoda nie jest doskonała. Próba łączenia różnych zagrożeń ekologicznych w jeden wskaźnik niesie ze sobą duże ryzyko, choć z drugiej strony obydwie zastosowane metody (ekologicznego deficytu i Eco-indicator 99) dały jednakowe wyniki. Znacznie większe wątpliwości wzbudza natomiast pominięcie potencjalnych efektów pośrednich związanych z rynkiem biopaliw, np. zależności między wzrostem zapotrzebowania na biopaliwa i powiększaniem terenów pod uprawy roślin energetycznych kosztem naturalnych ekosystemów oraz czynników ekonomicznych i społecznych. Poza tym, z powodu niekompletnych danych, autorzy nie uwzględnili w analizie niektórych biopaliw produkowanych z surowców ligninocelulozowych nieprzydatnych w przemyśle spożywczym [14, 19].

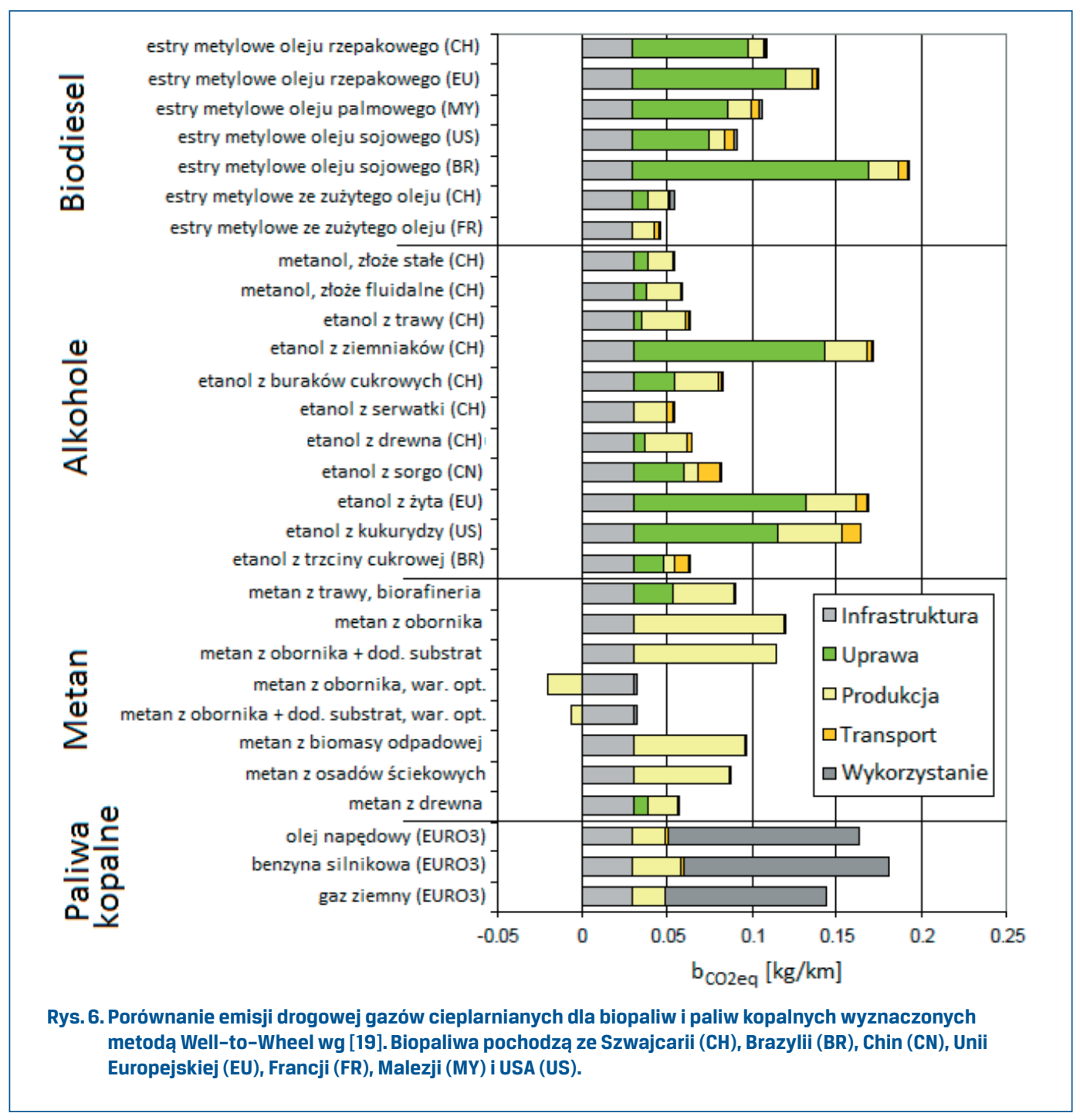




\section{Podsumowanie}

Dotychczas najbardziej rozpowszechnione metody kompleksowej oceny ekologicznej motoryzacji ograniczają się przede wszystkim do analizy energetycznej i analizy emisji zanieczyszczeń z pojazdów samochodowych z uwzględnieniem etapów wytwarzania i dystrybucji nośników energii i użytkowania samochodów. Wiedza na temat sposobów oceny właściwości ekonomicznych ze względu na zużycie paliwa oraz ekologicznych ze względu na emisję zanieczyszczeń w czasie użytkowania pojazdów jest dużo bogatsza niż w wypadku etapu przygotowywania paliw, mimo że i w wypadku użytkowania pojazdów pozostaje wiele trudnych do ujednolicenia uwarunkowań, determinujących wyniki oceny. Najważniejsze niepewności są związane z identyfikacją warunków pracy silników spalinowych, mających wpływ na stany pracy silników, determinujące szczególnie silnie emisję zanieczyszczeń. W porównaniu jednak z tymi problemami wrażliwość właściwości ekologicznych i energetycznych procesów wytwarzania nośników energii na rozpatrywane nośniki i sposoby ich wytwarzania jest nieporównywalnie większa. Uzasadnia to celowość rozpatrywania wyników analiz nie tylko w postaci łącznej, ale i osobno, w wielu wypadkach bowiem w procesach produkcji i dystrybucji nośników energii mogą się mieścić znaczne rezerwy, podczas gdy na etapie użytkowania pojazdów możliwości zmian są zazwyczaj niewielkie. Wynika z tego, że możliwe korzyści na etapie użytkowania pojazdów są znacznie bardziej pożyteczne niż na etapie dostarczania nośników energii.

Drugi poważny problem to sposób traktowania zanieczyszczeń. W powszechnie przyjętej modzie jako najważniejsze zanieczyszczenia, utożsamiane niejednokrotnie z właściwościami ekologicznymi, traktuje się gazy cieplarniane, a zazwyczaj wręcz tylko dwutlenek węgla, często zapominając, że w wypadku wykorzystywanych odnawialnych nośników energii powinno się to odnosić jedynie do dwutlenku węgla kopalnego. Jest to podejście nie tylko niesłuszne, ale i szkodliwe, najbardziej groźne są bowiem dla ludzi substancje szkodliwe dla ich zdrowia w sposób bezpośredni. Spotyka się sposoby tworzenia metod oceny kompleksowej z uwzględnianiem emisji substancji szkodliwych dla zdrowia ludzi i sprzyjających intensyfikacji zjawiska cieplarnianego. Przykładem takiego podejścia wydaje się być propozycja zawarta w dyrektywie 2009/33/WE w sprawie promowania ekologicznie czystych i energooszczędnych pojazdów. W rzeczywistości w dyrektywie tej nie rozróżnia się dwutlenku węgla kopalnego i dwutlenku węgla niekopalnego, co stawia w sytuacji przegranej stosowanie paliw odnawialnych. Słuszne jest zatem odrębne stosowanie wskaźników dotyczących emisji samych substancji szkodliwych dla zdrowia ludzi i odrębne wskaźników dotyczących emisji substancji szkodliwych dla środowiska. Ze względów humanistycznych priorytetowymi w ocenach kompleksowych motoryzacji powinny być zatem wskaźniki dotyczące emisji substancji szkodliwych dla zdrowia ludzi w etapie użytkowania pojazdów, bo charakteryzują one najgroźniejsze i bezpośrednie niebezpieczeństwo dla ludzi w związku z motoryzacją.

Autorzy proponują zatem następującą systematykę wskaźników do kompleksowej oceny bilansu energetycznego i emisji zanieczyszczeń z pojazdów samochodowych na etapie wytwarzania i dystrybucji nośników energii (etap WtT) oraz użytkowania pojazdów (etap TtW): 
- wskaźniki charakteryzujące emisję substancji szkodliwych dla zdrowia w etapie WtT, oznaczone jako: emisja drogowa $\mathrm{b}_{\text {tox } \mathrm{Wt}_{\mathrm{T}}}$ energetyczny wskaźnik emisji $\mathrm{WE}_{\text {tox } \mathrm{Wt}^{\prime}}$

- wskaźniki charakteryzujące emisję substancji szkodliwych dla środowiska w etapie WtT, oznaczone jako: emisja drogowa $\mathrm{b}_{\text {eco WtT' }}$ energetyczny wskaźnik emisji $\mathrm{WE}_{\text {eco } \mathrm{WtT}^{\prime}}$

- wskaźniki charakteryzujące efekt energetyczny w etapie WtT, oznaczony jako sprawność $\eta_{\mathrm{wt} \mathrm{T}^{\prime}}$

- wskaźniki charakteryzujące emisję substancji szkodliwych dla zdrowia w etapie $\mathrm{TtW}$ oznaczone jako: emisja drogowa $\mathrm{b}_{\text {tox Ttw' }}$, energetyczny wskaźnik emisji $\mathrm{WE}_{\text {tox TtW' }}$

- wskaźniki charakteryzujące emisję substancji szkodliwych dla środowiska w etapie $\mathrm{TtW}$, oznaczone jako: emisja drogowa $\mathrm{b}_{\text {eco TtW'}}$ energetyczny wskaźnik emisji $\mathrm{WE}_{\text {eco TtW' }}$

- wskaźniki charakteryzujące efekt energetyczny w etapie TtW, oznaczony jako sprawność $\eta_{\mathrm{TtW}}$.

Jako priorytetowy w kompleksowej ocenie ekologicznej motoryzacji należy uznać wskaźnik charakteryzujący emisję substancji szkodliwych dla zdrowia w etapie TtW, tzn. użytkowania pojazdów samochodowych.

Autorzy są przekonani, że rozwaga decyzyjnych przedstawicieli społeczeństw przychyli się do racjonalnego traktowania spraw ochrony środowiska przed skutkami motoryzacji i że kompleksowa ocena szkodliwości motoryzacji będzie pomocna w tym przedsięwzięciu.

\section{Literatura}

[1] AHLVIK P., BRANDBERG Å.: Well-to-Wheel efficiency for alternative fuels from natural gas or biomass. A report for the Swedish National Road Administration, EcoTraffic, 2001.

[2] BARNETT M. O.: Biofuels and greenhouse gas emissions: green or red? Environmental Science \& Technology, 44, 2010, ss. 5330-5331.

[3] BRINKMAN N., WANG M., WEBER T., DARLINGTON T.: Well-to-Wheels Analysis of Advanced Fuel/Vehicle Systems - A North American Study of Energy Use, Greenhouse Gas Emissions, and Criteria Pollutant Emissions. May, 2005.

[4] CHŁOPEK Z., Gis W., Waśkiewicz ].: Zastosowanie biogazu do zasilania silników autobusów miejskich. Rozdział W monografii „Energia niekonwencjonalne i zagospodarowanie odpadów". Lublin 2010, ss.103-116.

[5] CHŁOPEK Z.: Bilansowanie emisji zanieczyszczeń z silników autobusów miejskich. Transport Samochodowy 3/2009, ss. $55-70$.

[6] CHŁOPEK Z.: Ekologiczne i ekonomiczne aspekty eksploatacji silników o zapłonie samoczynnym na paliwo bioetanolowe. Transport Samochodowy 2/2008, ss. 37-50.

[7] CHŁOPEK Z.: Pojazdy samochodowe. Ochrona środowiska naturalnego. WKŁ, Warszawa 2002.

[8] CHŁOPEK Z.: Zastosowanie biopaliw w transporcie. Konferencja Naukowa "Transport 2008". Lublin, 7 marca $2008 \mathrm{r}$.

[9] Energy Independence Now: How do Hydrogen Fuel Cell Vehicles Compare in Terms of Emissions and Energy Use? A Well-to-Wheel Analysis. 
[10] EPA Lifecycle Analysis of Greenhouse Gas Emissions from Renewable Fuels. U.S. Environmental Protection Agency, Washington, DC, 2010.

[11] FRISCHKNECHT R., STEINER R., BRAUNSCHWEIG A., EGLI N., HILDESHEIMER G.: Swiss Ecological Scarcity Method: The New Version 2006. http://www.esu-services.ch/download/Frischknecht-2006-EcologicalScarcityPaper.pdf

[12] http://www.pre.nl/eco-indicator99/

[13] Napędy hybrydowe, ogniwa paliwowe i paliwa alternatywne. Informator techniczny BOSCH. WKŁ, Warszawa 2010.

[14] SCHARLEMANN J. P. W., LAURANCE W. F.: How Green Are Biofuels? Science, 319, 2008, ss. 43-44.

[15] SITNIK L. J.: Ekopaliwa silnikowe. Oficyna Wydawnicza Politechniki Wrocławskiej, Wrocław 2004.

[16] The Eco-indicator 99. A damage oriented method for Life Cycle Impact Assessment. Methodology Report. Pre Consultants B. V. Amersfoort, 2001.

[17] UNNASCH, S.: Alcohol Fuels from Biomass: Well-to-Wheel Energy Balance. Proceedings of the 15th International Symposium on Alcohol Fuels (ISAF), San Diego, California, United States, 26-28 September 2005.

[18] Well-to-Wheels amalysis of future automotive fuels and powertrains in the European context. WELL-toWHEELS Report, Version 2c. EUCAR/CONCAWE/JRC, March 2007.

[19] ZAH R., BÖNI H., GAUCH M., HISCHIER R, LEHMANN M., WÄGER P.: Ökobilanz von Energieprodukten: Ökologische Bewertung von Biotreibstoffen. EMPA, St. Gallen, Switzerland, 2007. 